\title{
World Society and the Global Foreign Aid Network*
}

\author{
Liam Swiss \\ Department of Sociology \\ Memorial University \\ lswiss@mun.ca
}

Final Submission Version

Forthcoming in Sociology of Development

\begin{abstract}
This article analyzes the relationship between foreign aid and globalization to explain developing country ties to world society and argues that foreign aid can be viewed as a recursive mechanism through which donor states refine and spread international norms and organizational ties. Using network data on foreign aid relationships between countries this article analyzes the effects of aid on human rights treaty ratification and international organization memberships in a sample of 135 less developed countries from the period of 1975-2008. Results of random effects panel regression models show that increased aid network centrality brokers increased country ties to world society, supporting a novel interpretation of foreign aid as a transnational process of political globalization.

Keywords: Foreign Aid; World Society; Globalization; Network Analysis; Human Rights; Civil Society
\end{abstract}

\footnotetext{
${ }^{*}$ I would like to thank Jason Beckfield, Andrew Dawson, Kathleen Fallon, and Wesley Longhofer for their helpful feedback on earlier drafts of this article. This research was supported by a grant from the Social Sciences and Humanities Research Council of Canada.
} 


\section{World Society and the Global Foreign Aid Network INTRODUCTION}

Why do states from diverse regions and governing diverse societies look so similar while doing it? This puzzle is the primary focus of sociological research on the politics of globalization and the concurrent growth of global civil society or the World Society. Explanations are offered for why states appear to be structured so similarly (Meyer et al. 1997a), how international organizations adopt and promote common frameworks to states (Boli and Thomas 1999), and, more recently, why the effects of world society are felt unevenly in different regions (Beckfield 2003, 2008, 2010). This last aspect of the world polity requires further attention. It is perhaps unsurprising that the impact of a 'world' society seems to disproportionately engage the developed West - or using World Systems Theory terminology, the Core - at the same time as it seems only to penetrate the developing world (Periphery) in more limited ways; the western origins of much of the world cultural content are not disputed (Meyer et al. 1997a). Indeed, the institutions and norms of legitimate statehood or organizational form reflect distinctly western institutions of civil society and state structures. Furthermore, the nature of world cultural models and institutions is such that weaker states have been shown to be only loosely coupled to their actual implementation (Clark 2010; Swiss 2009). More attention needs to be paid to how states on the margins of the world polity are embedded in and encouraged to adopt the institutional forms and models of world society. This paper examines the role foreign aid plays in this process.

World society research focuses extensively on the processes through which norms and institutions are diffused among states. Less attention has been paid to the recursive relationship 
of states to the world polity, and how states refine these institutions and norms and contribute to the evolution of world society's cultural content. Arguably, these recursive mechanisms are a means through which states play an active role in shaping future iterations of world society models. Recursive mechanisms that play a part in state-level enactment of world cultural scripts are likely the chief means by which states help to actively spread institutional models rather than having them spread passively through mimesis. This article argues that one mechanism through which states actively reshape parts of the world that are less embedded in the world polity is the process of bilateral foreign aid. In contrast to earlier research suggesting aid flows to countries that adopt world cultural models (Barrett and Tsui 1999), I argue that foreign aid acts as a relationship through which the wealthy donor states - highly embedded in the world polity - act as brokers to promote institutions and norms of legitimate statehood in the developing world, increasing the embeddedness of recipient countries in world society. Aid acts as a transnational process which rectifies some of the inequality Beckfield and others identify in world society's structure.

This article analyzes how state-to-state (bilateral) foreign aid promotes developing country embeddedness in world society in three ways: (1) through the ratification of human rights treaties; and through membership in (2) intergovernmental organizations; and (3) international non-governmental organizations. Following from research which uses social network methods to focus on the role that networks and ties between state actors play in shaping global processes of socialization, diffusion, and conflict (Carpenter et al. 2014; Hafner-Burton, Kahler and Montgomery 2009; Hafner-Burton and Montgomery 2006; Ward, Stovel and Sacks 2011), the theoretical innovation I make here is that aid matters for world society embeddedness not by virtue of the amount of funding provided by donors, but by the number of donors from 
which a country receives aid. I use newly compiled data on the global foreign aid network to assess whether states with a more diverse network of aid ties - those which are more central to the global aid network - are likely to be more embedded in world society in the form of treaty ratifications and organization memberships. My findings show that, in concert with numerous other influences, receipt of foreign aid from a greater number of donor countries increases the integration of developing states into world society. This casts aid as a relational transnational process through which wealthier Western donor states broker ties to international organizations or treaties and provide a resource base to influence developing countries to become more adherent to world society norms of legitimate statehood (Peterson 2014; Swiss 2016).

\section{WORLD SOCIETY INFLUENCE ON STATE INSTITUTIONS AND POLICY}

The World Society approach argues that the global collection of international organizations, treaties, conferences, and other rationalized actors are responsible for political globalization in terms of the spread of common institutions and policies among states (Meyer et al. 1997a). World society is responsible for construction and diffusion of 'world cultural' norms of legitimate statehood, including models of citizenship (Berkovitch 1999), human rights (Cole 2012; Wotipka and Ramirez 2008), social services (Schofer and Meyer 2005), and even environmental protection (Frank 1997; Frank, Longhofer and Schofer 2007; Meyer et al. 1997b; Schofer and Hironaka 2005).

Key measures of how world society influences states have tended to examine two specific aspects: (1) embeddedness in the world polity; and (2) the density of world cultural models. Embeddedness has frequently been measured by the number of ties that states have to international non-governmental and intergovernmental organizations (Beckfield 2003, 2008; 
Boli and Thomas 1999; Frank 1997; Hughes et al. 2009; Paxton, Hughes, and Reith 2015) and/or the number of international treaties and conventions that have been ratified by a state (Clark 2010; Hafner-Burton and Tsutsui 2005; Wotipka and Ramirez 2008). Similarly, the density of world society norms/models had frequently been indicated by the number of states that have previously adopted similar institutional frameworks and models (Swiss 2012; Jang 2003; Ramirez et al 1997; Wotipka and Ramirez 2008). In this article I deploy similar measures of treaty ratification and international organization memberships to proxy the embeddedness of states in world society.

\section{INEQUALITY AND THE STRUCTURE OF THE WORLD POLITY}

The embeddedness of states in world society is not uniform. Research suggests that, despite the theoretical notions of world society promoting universal norms and institutions, these institutions and models do not penetrate states equally (Swiss 2009; Clark 2010; Beckfield 2003, $2008,2010)$. Instead, the structure of the world polity reflects some of the inequalities inherent in the 'world system' perspective with countries of the core more closely enmeshed in world society's networks of international organizations and countries of the semi-periphery and periphery less connected (Beckfield 2008). This uneven distribution of ties to world society is present in the case of both intergovernmental and international non-governmental organizations and still disproportionately marginalizes countries of the developing world (Beckfield 2003, 2008; Hughes et al. 2009; Paxton et al. 2015). Furthermore, IGO ties, where developing nations are closer to par with the developed west, are becoming more regionalized - states are more likely to join IGOs that share members from their region than to be linked to all states through global IGOs (Beckfield 2010). 
This increasingly regional character of country membership in organizations that structure world society challenge the conventional depiction of a global network of lookalike actors aligned behind a uniform world culture. Indeed, the regional fragmentation of these networks in a way that parallels divisions typical of a World Systems understanding of political and economic globalization directly contradicts the concept of a universal world culture spread by world society actors. Such universality and uniformity is also challenged by the notion of loose or full de-coupling states and other actors experience when applying world society norms/models (Clark 2010; Cole 2012; Cole and Ramirez 2013; Swiss 2009). As Clark (2010) illustrates, even in cases where developing states tacitly embrace world society norms, they are much more likely to be only loosely coupled to the intended application of such models. To account for these regional and developmental causes of variation in embeddedness, my analysis includes a regional categorical indicator and several measures reflecting economic and political development (GDP per capita, trade, democracy). If countries' ties to world society are increasingly regionalized, and the developing world remains more loosely coupled to the world society norms, then gaining a better understanding of possible efforts to more closely integrate the developing world/periphery into world society merits closer inspection.

\section{FOREIGN AID, RECURSIVE PROCESSES, BROKERAGE, AND ISOMORPHISM}

Theoretical discussions on the world society perspective suggest it relies on recursive processes through which actors (states, organizations, and citizens) actively reshape the "world institutional and cultural order" through their refinement and enactment of existing models (Boli and Thomas 1999; Meyer et al. 1997a). An inherent part of the world polity theoretical framework, these recursive processes have received less attention than enactment and diffusion 
processes. Chorev introduces us to one such recursive mechanism: 'reactive diffusion', where changes to norms emerge from local instances of decoupling, particularly in the developing world (2012). Complementing such reactive processes, this article argues that foreign aid is a process through which donor nations actively reshape and reflect world society norms upon the recipient countries of the developing world. In essence, donor states adopt global norms and policy scripts earlier, refine them through their experience of adoption and implementation, and then promote them in recipient countries through aid programs and the ties they create between donor and recipient states. Through these donor-recipient ties, donors broker new connections of recipient countries to international organizations and institutions, further embedding them in World Society. Following Tvedt's (2006) call to analyze the relationship between donors and international NGOs, Peterson $(2011,2014)$ identifies this brokerage role by analyzing the association between aid and the increasing presence of international organizations in developing countries, arguing that Western aid can be viewed as a 'gift' which can strengthen developing country ties to the global community. Likewise, Jackson (2005) argues that aid workers and organizations play a role in promoting global integration of developing states. Western aid agencies also experience a significant degree of world society influence that shape donor aid priorities (Swiss 2011, 2012), so it is logical given their role in channeling ideas, expertise, and resources to the developing world that the content of foreign aid would be decidedly 'world cultural' in scope. Beyond reflecting world cultural norms and frames, earlier research also demonstrates the role aid plays in spreading certain organizational forms, with increased aid leading to a greater number of domestic associations formed in a country over time (Schofer and Longhofer 2011). 
A variety of motives have been ascribed to foreign aid, it is ostensibly aimed at 'development' as a goal, but in the process, leads to the proliferation of common practices and institutional forms - aid spreads isomorphism (Tvedt 2006; Fejerskov 2015). Foreign aid can promote the adoption of common framework and institutions through what Dimaggio and Powell (1983) label 'coercive isomorphism'. Aid, in this respect, offers financial incentive for recipient states to adhere to international norms or expectations. Barrett and Tsui's (1999) findings regarding the correlation of increased American aid flows to countries adopting national population policies are evidence of this relationship: states receive aid if they adopt the proper policies.

I argue, however, that aid functions through other forms of isomorphism. Beyond simply a transfer of funds from one country to another, aid funds buy 'expert' knowledge transfer and broker connections to international organizations that hold specific expertise. In this way, aid allows developing nations to connect with epistemic communities surrounding specific institutional norms and forms. Akin to Dimaggio and Powell's normative isomorphism, Babb labels this 'expert isomorphism' in her study of banking in Mexico (2001). Many aid projects are created to promote reform to government systems by connecting states to outside expertise: environmental regulations, human rights practices, civil society capacity, and other parts of the state are all targeted by development initiatives funded by bilateral aid. Aid donors broker these ties and pay many of the costs of the resulting reform work.

Take, for example, support of aid donors for human rights reforms. A dataset of all bilateral aid projects reported by the 23 donor country members of the OECD Development Assistance Committee in 2000-2001 reveals five different donors funding national human rights 
commissions in countries in both sub-Saharan Africa (Nigeria, Zambia, Rwanda) and across Asia (Indonesia and a regional initiative for the Asia-Pacific) to better implement human rights (OECD 2013). In 2011, the same dataset reveals more than 90 such projects supporting the work of human rights commissions in countries across Africa, Asia, and the Middle East. Given the role these bodies have been shown to play in increasing the enforcement of rights, and shifting the context of rights abuses in countries over time (Cole and Ramirez 2013; Koo and Ramirez 2009), donor support for such institutions is but one example of how aid can foster the spread and institutionalization of global norms by connecting recipient countries to relevant resources and expertise (Tvedt 2006). These projects and the international organizations with expert (usually expatriate) knowledge on which they rely spread common approaches to governing and statehood from North to South (or in some instances South to South) and can be seen as conduits for the norms and institutional models of world society. Donors actively broker recipient relationships with the relevant international NGOs and inter-governmental organizations best placed to aid in these reforms. In this way, foreign aid plays a recursive role shaping world culture at the same time as it shapes the developing world through brokering the spread of world cultural norms and increased ties to the global community.

Apart from carrying the cultural, normative, and institutional content of world society from donor to recipient, aid flows are also frequently 'carried' by organizations and individuals that comprise the 'rational others' of world society: international non-governmental organizations, intergovernmental organizations, private sector firms, expert consultancies, and scientists are all frequently the implementers of bilateral aid programs (Tvedt 2006). Viewing aid relationally through a social network lens, the ties that donor countries broker between recipient countries and these organizations further facilitates this carrier role (Swiss 2016). 
Hughes and co-authors hint at this role when discussing the western origins of world culture: "If policy scripts originate from developed, Western states, then INGOs may serve as nothing more than carriers of Western ideals" (2009: 115). Given that so little bilateral aid consists of donor agencies themselves carrying out the work 'on the ground', foreign aid relies heavily on delivery by executing agencies that double as the 'rational others' of world society and carry these world cultural ideals. For instance, of the over 190,000 bilateral aid projects reported to the OECD by its donor country members in 2011, more than 100,000 projects worth more than $\$ 50 \mathrm{~B}$ USD flowed through non-governmental, IGO, and 'other' groups. This underscores the extent to which aid delivery is reliant on these groups and the ties to them brokered by donor countries. It is these 'rational others' that Meyer writes "are desperately needed to provide instruction, consulting, and repair, as every actor requires help living up to expanded standards" (2010: p. 14). Foreign aid funds make this instruction, consulting, and repair happen.

Viewing aid in this light suggests aid attempts to correct some of the inequity in the world polity (Beckfield 2003). Donor countries, already more deeply enmeshed in the INGO and IGO networks of world society, provide aid to recipient countries on the periphery of these networks and in doing, help to broker greater ties for recipient countries to these networks. Foreign aid in this view can be seen as incentive (coercive isomorphism), knowledge/best practices (normative or expert isomorphism), and connection (brokerage) to help recipient countries become more tightly coupled to the models and embedded in the institutions of legitimate statehood in the world polity. It is this latter process of connection and brokerage on which this study focuses. 
What does this encouragement of institutional isomorphism and world society embeddedness in the developing world look like? A range of mechanisms might be employed, but in this article I propose two network mechanisms through which donor influence operates: (1) donor network brokerage; and (2) network exposure/emulation. Through brokerage, donors connect recipients to relevant expertise and actors in world society that further the adoption and implementation of global norms as well as embed recipients in global networks (Gould 1989; Gould and Fernandez 1989). Likewise, through exposure, recipients more central to networks where donors have already adopted treaties, norms, and institutions of world society are exposed to more examples of this behavior to emulate. These mechanisms are visible in several common aid practices: (1) aid brokering recipient country ties to INGO/IGO groups and networks; (2) aid brokering recipient country participation in IGOs; (3) aid to international organizations - both INGOs and IGOs - brokering delivery of development programming in recipient countries.. The close association between aid, international actors, and international norms is evident in both of these mechanisms and their associated practices. Though ostensibly intended to promote 'development' by reducing poverty, development assistance is equally aimed at enhancing recipient state ties to global norms and actors. These mechanisms are apparent in the work of bilateral aid donors globally, yet the nature of the relationship between aid and a countries' embeddedness in the norms and organizations of world society remains little understood. I analyze this relationship in the next section and then return to the proposed mechanisms in the Discussion section that follows.

\section{THE GLOBAL FOREIGN AID NETWORK}


As I have argued elsewhere (Swiss 2016), understanding foreign aid as a relational process through which donor states diffuse world society norms and ties, requires considering aid from novel perspective: the position of a recipient within the global aid network. The past preoccupations of the foreign aid literature with the volume of aid received or extent to which a recipient is dependent on aid might imply that it is only the amount or level of aid that matters for world society embeddedness. A network approach requires that we ask what role is played by the ties between countries and organizations built by the aid process? This article argues that these network factors play a critical, but understudied role.

\section{Aid Networks}

Researchers have begun to focus on relationships between states internationally through the lens of social networks (Hafner-Burton, Kahler and Montgomery 2009; Hafner-Burton and Montgomery 2006; Ward, Stovel and Sacks 2011). Rather than focusing on trade flows or agreements between states, the position of states in global networks has been identified as an equally important factor in shaping agenda-setting, diffusion and socialization processes internationally. States that are more central to global networks have been characterized by Beckfield (2003) as able to shape the world polity agenda, while those with fewer ties are marginalized. Likewise, states that are more central to global networks can be viewed as having access to greater resources, information, and social capital through these relationships (HafnerBurton, Kahler and Montgomery 2009). It is in this context that I analyze foreign aid as a global network of relations between states and societies (Peterson 2014; Swiss 2016).

The aid relationship represents more than the simple transfer of funds and expertise. Conceptualised as a network of ties between states through which institutions and norms are 
transferred. It is surprising, therefore, so little research examines foreign aid relationships at the global level from a social network perspective. Peterson (2011) has the only major study on the subject and demonstrates the promise of a network approach to examining foreign aid. Peterson investigates the connection between a country's "aid attractiveness" (eigenvector network centrality) and INGO membership (and vice versa) over time using cross-lagged panel models and finds an association between aid attractiveness and the number of INGOs in a country, but does not address other manifestations of world society embeddedness addressed in this article. Aside from Peterson's work and a study examining the effects of network centrality on development NGOs responding to disaster in one country (Moore, Eng and Daniel 2003), there has been little attempt to understand global foreign aid as a network of relationships between states or how a country's position in that network might shape their embeddedness in world society or adherence to global norms (Swiss 2016).

\section{[FIGURE 1 HERE]}

\section{[TABLE 1 HERE]}

This article presents network data on bilateral aid flows between countries and argues that aid network centrality is a key feature to understand the extent to which donors can influence recipient country embeddedness in world society. This network has grown significantly over time. Figure 1 depicts two snapshots of the global bilateral foreign aid network: in 1975, and in 2005. Both visualizations are organized by network centrality: the larger the node and the closer it is to the center of the diagram, the more central the country in the global network. Donor nodes are the dark circles; recipient nodes are rounded rectangles. Table 1 shows network indegree (number of incoming donor ties) centrality scores for all 133 countries in the final sample used in 
the models. The ties between donors and recipients are more identifiable in the earliest snapshot in 1975 which shows a network with a total of 1217 aid ties, a network density of 0.028 . This represents rapid growth, given that in the initial year for which data is available (1960) the network consisted of only 258 ties. These ties quickly dissolve into a cloud of complexity over

the years. In the bottom portion of Figure 1, the 2005 network reflects this increased complexity with a total of 2,672 network ties and an overall network density of 0.063 ; this growth represents a more than ten-fold increase. This growth reflects four trends: (1) more recipient countries receiving aid; (2) more donor countries providing aid; (3) recipient countries receiving aid from a greater number of donors; and (4) donors providing aid to a greater number of recipients.

\section{[FIGURE 2 HERE]}

As the global foreign aid network has expanded we can see a corresponding growth in country ties to the world polity. Figure 2 illustrates these parallel trends, plotting the growth in total global aid network ties on the left-hand y axis and total global INGO membership ties on the right-hand y axis. In the same period that the global aid network has expanded massively, we see a similar growth in global INGO ties. The hypothesis I test here is whether countries more central to the global aid network - those having more donor ties, and therefore greater potential exposure to global networks of organizations and treaties - results in greater embeddedness in world society in the form of treaty ratifications and organizational memberships.

\section{Accounting for Aid Volume \& Dependency}

Aid network ties obviously do not exist in isolation from the aid funds that they facilitate. In this respect, any investigation of the aid network should account for the volume of aid flows 
and their relative import for various recipient countries. In the analysis that follows, I thus control for both aid volume and aid dependency.

Total volume of aid received by a country may also influence the adoption of institutions and policy models promoted by donor states. Greater volume of ODA means more funds for a recipient country to procure resources and expertise to reshape and reform their institutions, policies, and programs through the development process. In this way, net of aid network position, greater aid volume might help build on aid ties to strengthen world polity embeddedness.

Aid dependent countries are those where foreign aid funds make up an untenable proportion of total national income. Research on aid dependency suggests aid dependent countries are more susceptible to donor policy influence than those for whom aid funds are a less significant source of financing (Collier 1999; Moyo 2009; Moss, Petterson and van der Walle 2006). At the same time, aid dependent nations also tend to be some of the weakest states with the most limited institutions, tending to be loosely coupled to international norms and institutional frameworks (Clark 2010; Swiss 2009). In contrast to the aid network centrality and aid per capita measures above, therefore, I expect that countries receiving higher levels of aid as a percentage of national income - those most dependent on aid - will be less closely tied to the world polity.

\section{METHOD \& DATA}

\section{Sample \& Method}

Drawing from a sample of 150 countries for which I was able to compile aid network information, the models that follow use a sample that consists of all independent aid-recipient 
countries for which there was no missing data in a given year in the period 1975 through $2008{ }^{1}$ For former colonies or newly formed states, countries enter into the analysis following independence. The largest sub-sample with available data represents 135 countries from five regions, representing 3,306 country-year observations. I employ two different modelling strategies. For the count of human rights treaty ratification I use random effects negative binomial panel regression, while for INGO and IGO memberships I model the data using random effects panel regression. ${ }^{2}$

The benefits of random effects models include that we are able to account, not only for time-varying covariates within countries, but also those fixed factors such as region which account for heterogeneity between countries over time. In this case, a random effects approach enables me to model the influence of the regionalization of the organizational structures of the World Polity rather than simply treating regional characteristics as one fixed aspect of a country controlled for through a country-specific dummy in a fixed effects model. The dependent variables in my models each demonstrate $\mathrm{AR}(1)$ autoregressive disturbance over time, so my models account for this autocorrelation within countries over time using a modified error term. I adopt this approach rather than including a lagged dependent variable because the lagged variable in each case is highly collinear with the global and regional level counts I employ in the models to account for contagion or indirect effects, and because lagged dependent variables have been shown to frequently distort findings regarding other explanatory variables (Achen 2000).

\section{Dependent Variables}

My models analyze the effect of foreign aid on three specific manifestations of world society influence and embeddedness: 
Human Rights Treaty Ratification: This variable is a yearly count of ratification of the eight primary UN human rights treaties and their optional protocols by each country. ${ }^{3}$ Yearly counts range from 0 to15 in the sample, with a mean of 4.86 ratifications.

International Non-Governmental Organization (INGO) Memberships: This variable is a count of national memberships in international non-governmental organizations based on Union of International Association data from 1975-2008. INGO memberships range from 0 to 2,666 in the sample, with a mean of 491.5 memberships. ${ }^{4}$

Intergovernmental Organizations (IGO) Memberships: This variable is a count of national memberships in intergovernmental organizations based on Union of International Association data from 1975-2008. The sample mean for IGO memberships is 42.13 , ranging from zero to 87 memberships.

In my models, I use the three-year lead of each dependent variable to build some degree of temporal priority into my analysis, and to account for a period in time in which aid projects/programs may begin to have an effect once commenced. ${ }^{5}$ For instance, the treaty, INGO, and IGO counts for 2008 are regressed on explanatory variables from 2005. This lead time does not imply causation, but allows for the effects of foreign aid and other factors to exert influence in that three-year period.

\section{Independent Variable}

The focal independent variable in my analysis is Global Foreign Aid Network In-degree Centrality: I collected data on all bilateral ODA aid flows between countries from 1960-2010 using the Organisation for Economic Cooperation and Development's Query Wizard for 
International Development Statistics (QWIDS) system. Data were transformed into a bimodal social network matrix where the presence of any positive flow of ODA funds from donor to recipient was coded as a network tie. ${ }^{6}$ Network matrices were prepared for each year from 1960 through 2010. Using the UCINet software package, I calculated Freeman in-degree centrality scores and eigenvector centrality for each country, but use the former as the network centrality measure in the models that follow. ${ }^{7}$ In this case, in-degree centrality represents the total number of donor countries providing aid to a recipient country in a given year. I use this variable to measure the extent to which recipient countries in the developing world are more or less central to the global flow of foreign aid. Aid network centrality scores range from 0 to 28 in my sample, with an overall sample mean of 14.46 .

\section{Aid Controls}

As indicated in the literature review, aside from the effects of aid network centrality, I also control for two other aspects of a recipient countries aid experience: volume and dependency.

Aid Volume: This is a measure of ODA per capita in constant 2005 US dollars and is drawn from the World Bank's World Development Indicators dataset (2010). This measure accounts for the differential impact of ODA funds between countries with differing populations. Aid per capita ranges from $-\$ 33$ to over $\$ 14,000$ in my sample, with an average of $\$ 69$ per person. Negative values of aid per capita reflect those countries which repaid more aid debt in a given year than new aid they took in. 
Aid Dependency: This is a measure of ODA as a percentage of gross national income drawn from the World Bank's World Development Indicators dataset (2010). This measure indicates the relative importance of aid as a source of financing for the country in comparison to all income sources it possesses and is frequently used as a measure for 'aid dependency.' Countries with the highest levels of aid as a percentage of national income are those where aid dependency is strongest. The average level of ODA as percent of GNI in the sample is $7.3 \%$.

\section{Regional Controls}

Given Beckfield's (2003, 2008, 2010) findings regarding regionalization and inequality in the World Polity, and Hughes et al.'s (2009) findings about regional ties to INGO networks, I expect the treaty ratifications and organizational memberships I examine here to follow similar regional patterns. Those regions which are more peripheral to economic and political power on the global stage are likely to have fewer ties and organizational memberships. Five regions in my country sample are controlled for in all models as a categorical measure with Sub-Saharan Africa as the reference category.

\section{Economic Controls}

Two controls for socio-economic status are included in my models:

Logged GDP Per Capita: GDP per capita (constant US dollar) values are drawn from World Development Indicators dataset (World Bank 2010).

Trade: The level of trade in a country's economy is measured by the percentage of Gross National Income composed of goods and services exports (World Bank 2010). 


\section{Democracy Control}

To account for the effects of democracy I include the following measures in my models:

Democracy (Polity IV): Commonly used as a cross-national comparative measure of democracy, the Polity IV score ranges from -10 (authoritarianism) to 10 (democracy). Missing values for micro-states and other missing values were filled using the extension of the Polity IV data prepared by Gerring and coauthors (2005).

\section{World Society Controls}

World Society Density: To account for increased density of world society norms, institutions, and organizations more broadly at the global level, I include a global and regional means of human rights treaty ratifications, INGO memberships, and IGO memberships in the respective models. These variables aim to account for the density, contagion, or norm cascade effect identified in much of the world society literature that suggests the prior behaviour of other countries globally often is associated with the eventual adoption of similar institutions by late-adopters (Ramirez, Soysal and Shanahan 1997; Schofer and Longhofer 2011; Wotipka and Ramirez 2008).

Decades: The research literature on world society has emphasized the extent to which the norms, institutions, and organizations that comprise it have grown considerably over the past decades. To control for the growth and expansion of World Society over time, I include dummy variables for decade, with the reference category reflecting observations in the 1970s. 


\section{RESULTS}

Model results for the three dependent variables are shown in Tables 2-4. Following Gelman (2008), in each analysis, each continuous variable has been standardized by dividing by two standard deviations. This facilitates interpretation of coefficients as the difference between a low and high value (mean \pm 1 standard deviation) of the variable. This makes coefficients more easily comparable across variables of diverse scale and akin to understanding the effect of an untransformed dichotomous variable. Per Gelman, in the results that follow I discuss the difference between low and high values of numeric variables as shorthand for this two standard deviation standardization. ${ }^{8}$

Each table proceeds in the same fashion: Model 1 includes controls; Model 2-4 include the three aid measures; and finally Models 5 and 6 include the unconstrained models including all covariates. ${ }^{9}$

\section{[TABLE 2 HERE]}

Table 2 reports the results for the relationship between foreign aid and human rights treaty ratification. Incidence rate ratios (IRR) are reported for each variable. These results support the aid networks hypotheses, but reveal that aid volumes have an effect opposite that hypothesized, and that aid dependency has no significant effect. Aid network centrality is positively related to human rights treaty ratification. Using the IRR from Model 5, a country with a high level of aid network centrality would be predicted to have 10 percent more treaty ratifications than a country with low ties, all else equal. In contrast, a similar change in aid per capita, reduces treaty ratifications by 14 percent. This counterintuitive finding for the aid volume 
control likely stems from the fact that several of the countries with the highest levels of aid per capita in my sample tend to be very small island nations with limited human rights regimes and ratifications. The aid network centrality effect also holds when controlling for aid dependency in Model 6, but the aid dependency hypothesis is not supported. Overall, the relationship between aid network centrality and treaty ratification is as predicted. The size of the effect of aid network centrality is diminished in the full models once the world polity controls are included, but still positively influence treaty ratification. ${ }^{10}$ Independent of how much aid per capita is supplied by donors or how dependent a recipient country is on aid as a proportion of its national income, countries with a higher number of donors ratified a greater number of treaties.

The full models in Table 2 also reveal interesting patterns with the control variables. In keeping with the hypothesized regional cleavages, countries in Latin America and Eastern Europe have significantly higher numbers of treaty ratifications than sub-Saharan Africa, while countries in the Asia-Pacific ratify fewer: this suggests support for Beckfield's (2003) 'conflict model' of world society. The economic controls have no remarkable effect once included in either full model, while an increase to high levels of democracy predicts a $14-15 \%$ higher number of treaty ratifications in Models 5 and 6. Not surprisingly, the macro-level time and contagion/diffusion influences of earlier treaty ratification are significant and positive, with positive effects of world and regional ratification levels (in Africa, the Middle East, and AsiaPacific), as well as decade on treaty ratification.

\section{[TABLE 3 HERE]}

Table 3 again shows support for the aid networks hypothesis, this time testing the relationship between foreign aid and INGOs memberships. Neither of the aid volume or aid 
dependency controls is associated with INGO memberships. Coefficients from Model 6 predict that a country with higher aid network centrality would hold approximately 31 more INGO memberships than a country at low levels of network centrality in any given year. Wealthier countries are more likely to have higher levels of INGO memberships, as higher levels of GDP per capita predict more than 143 memberships for a country in both Models 5 and 6 . Trade has no significant effect in the full models. More democratic countries are predicted to have more INGO memberships, with a higher Polity IV score resulting in approximately an additional 18 INGO memberships all else equal. The world polity effect of the global average of INGO memberships has a positive relationship to the dependent variable, while the regional effects are less consistent.

\section{[TABLE 4 HERE]}

The relationship between aid and intergovernmental organization memberships is reflected in Table 4. The predicted relationship between the aid network variable and the IGO membership count is similar in these models; however, the magnitude of the effect is less than in the INGOs membership case. Based on Model 5, a country with higher aid network centrality would have 1.75 more IGO memberships than a country with lower aid network centrality, ceteris paribus. Like in the INGO models, the controls for volume of aid and levels of aid dependency appear unrelated to the level of IGO memberships. Interestingly, the democracy measure is not significant in these models, suggesting that the nature of IGOs is that they are open to all comers deemed a legitimate state, democratic or not. Wealthier countries will have greater IGO ties, while trade levels show no effect. The effect of global levels of IGO membership is not significant, suggesting that at the global level, a higher level of collective IGO 
membership does not influence developing countries to join IGOs. In contrast, the regional IGO effects appear to be strong and positive in each of Africa, Latin America, and Eastern Europe, suggesting support for Beckfield's regionalization of the world polity findings.

Overall, the results show a robust relationship between aid network centrality and world society embeddedness. Viewing aid as a network relationship shows that ties to foreign aid donors influence the inclusion of developing countries in the world polity and have a strong effect on the globalization of international norms and institutional memberships.

\section{[FIGURE 3 HERE]}

Are the network effects of foreign aid consistent regardless of the controls for aid volume or aid dependency? In other words, do ties matter regardless of the size of aid investment they represent? To test this, I conducted interaction models between the aid network measure and the aid controls, but there were no significant interactions to report, suggesting that aid ties matter independently of the volume of aid a country receives. Likewise, given the regional variation and World System theory-like inequality in the world polity we might expect to see similar variation in the extent to which aid network ties promote world society connections. To test this proposition, I added an interaction effect between the level of economic development (GDP per capita) and aid network centrality to the full Models in Tables 1-3. Only in the case of IGOs was this interaction statistically significant, and showed a diminishing effect of aid network centrality as countries became wealthier. Figure 3 shows how the marginal effect of aid network centrality diminishes at higher levels of GDP per capita, although at the highest levels of GDP per capita, the predicted effect of aid ties is not significantly different from zero. This effect was not apparent in either of the treaty ratification or INGOs membership cases. For IGO memberships, 
at least, countries with higher levels of economic development have a lower net effect of aid donor ties than countries with less income per capita. This speaks directly to the role aid can play in potentially reducing the inequality in IGO memberships between world society's more central and more peripheral states.

\section{DISCUSSION}

Foreign aid plays a role in shaping less-developed nations' participation in the global community. My evidence suggests that ties to the global aid network, regardless the volume of aid, are key predictors of a state's connections to world society. Foreign aid network ties enhance diffusion and socialization processes through which donors encourage reforms in the developing world that increase recipient country ties to world society. These processes can be viewed as recursive as ties to donors which enable the transfer of world cultural scripts donors have already experienced, and broker ties to organizations that help developing countries to adopt the same. By promoting institutional adoption and reform in recipient countries, donors promote models they have previously adopted and are reshaping, refining, and helping to validate the institutions and norms of legitimate statehood or organizational structure in the world polity. Both donor and recipient countries enact world cultural scripts and recursively refine these scripts in conjunction with the rational actors of world society (Chorev 2012), but donors also play a role in spreading/diffusing these scripts and brokering organizational ties through bilateral aid to recipient countries on the margins of the World Polity.

\section{[FIGURE 4 HERE]}

\section{Network Centrality and Donor Brokerage}


Brokerage in social networks refers to a relationship in which one node in the network acts as an intermediary between two others (Gould and Fernandez 1989). A variety of brokerage relationships occur in social networks and depend on the strength of ties, structure of network, and content of the transaction or relationship between actors (Granovetter 1973; Hanneman and Riddle 2005; Täube 2004) through which another node becomes linked indirectly. Social network research has demonstrated that network nodes and have greater or lesser influence on processes of diffusion based on this brokerage role, with actors that bridge gaps between diverse network actors or sub-groups demonstrating the greatest influence (Murdie and Davis 2012; Hanneman and Riddle 2005).

Applied to my aid network data, the broker role for donor influence over World Society embeddedness is illustrated in Figure 4 above. Donors possessing membership ties to organizations and ratification ties to human rights treaties are able to act as intermediaries or liaisons and broker ties between organizations/treaties in their network to which a given recipient country may not be already connected. With a greater number of ties to world society actors and treaties than the recipient country, the donor in Figure 4 may broker new ties between the recipient and any other nodes in the organizational/treaty network to which it is connected. With a greater number of ties to donors in this position, the magnitude of potential brokerage effects multiplies quickly. In the case of the global aid network the brokerage 'reach' of a specific recipient's network can be conceptualized as the number of additional organizations or treaties to which a recipient might become linked through their aid ties to donors.

\section{[TABLE 5 HERE]}


To illustrate the potential scope for brokerage, in Table 5 I estimate the potential reach for a recipient country with the median number of donor ties every five years between 1975 and 2005. To estimate reach, I calculated the median INGO and IGO memberships and human rights treaty ratifications for both donors and recipients in each year, differenced the median scores, and multiplied by the median number of donor ties for recipients in that year. This crude measure represents the number of potential new ties donors might assist recipients in making. At its maximum (100\% reach), we can see that this would mean potential connections of the median recipient to between 7,700 and just over 40,000 INGOs between 1975 and 2005 and, on average, about 320 IGOs in the same period. In reality, donors are not likely to broker connections to every one of the INGOs and IGOs to which they are tied, so we can scale these numbers back and assume a lower extent of reach. Figure 5 plots low, middle, and high values for this brokerage reach for treaties, INGOs, and IGOs using lowess smoothing. Regardless of the extent of reach, there is a significant expansion in both the case of the treaties and INGOs to which donors might broker ties between 1975 and 2005. The IGOs to which donors might connect recipients fluctuates more over the same period, but still represent a significant pool of potential IGO memberships for recipients.

\section{[FIGURE 5 HERE]}

The theoretical models of brokerage offered by social network methods seem to fit the global aid network, but how does brokerage function in practice? Many common aid practices provide examples of how brokerage operates, but I will discuss three here: (1) aid brokering recipient country ties to INGO/IGO groups and networks; (2) aid brokering recipient country

participation in IGOs; (3) aid to international organizations - both INGOs and IGOs - brokering 
delivery of development programming in recipient countries. I briefly review examples of each of these practices below.

1. Aid brokering recipient country ties to INGO/IGO groups and networks: One example of brokerage by donors linking recipient country actors to INGO and IGO networks can be seen in American (USAID) support of anti-corruption and accountability efforts in recipient countries and globally through support to the global network Transparency International (TI) and its local chapters. For instance, support to TI Pakistan and TI Sri Lanka enables those local chapters of the INGO to grow in capacity and work with TI at the global level to promote norms of transparency and accountability in their own countries (USAID 2007; USAID 2010a; USAID 2010b). Helping to establish local NGO linkages with INGOs, is a means by which bilateral aid can be seen to broker ties that help to shape embeddedness in INGO networks in the developing world.

2. Aid brokering recipient country participation in IGOs: Donors also broker ties between recipients and important IGOs which work to shape the global normative agenda. Donor funding of recipient participation in IGOs' sometimes frequent and costly international conferences is one example of where bilateral aid donors broker recipient country participation in IGO forums and events.

Examples from recent high-level UN meetings are instructive. Searching the more than 160,000 project entries in the OECD Creditor Reporting Service dataset for the years 2000-2001 shows programs implemented by several donors (Canada, Norway, Sweden, and United Kingdom) aimed directly at supporting recipient country participation in the five-year follow-up conference to the Beijing Fourth World Conference on Women. This "Beijing +5 " review 
process entailed numerous preparatory meetings, workshops, as well as the June 2000 special session of the UN General Assembly at UN headquarters. Through such programs, participants from countries including Bangladesh, China, Kenya, the Democratic Republic of Congo, Yemen, and others were able to participate in the global Beijing +5 processes. In the 2011 OECD CRS dataset, similar support is shown by donors for recipient country participation in preparations for the 2012 UN Conference on Sustainable Development (Rio +20).

Beyond support to conference participation, aid can also be seen to help developing countries live up to IGO standards. Another example from the 2011 CRS data reveals the World Bank's International Development Association, the United States, Spain, the European Union, and Korea as donors supporting projects to assist developing country recipients in their efforts to better comply with the standards of the International Civil Aviation Organization (ICAO). Aid in this case helps recipient countries in "living up to expanded standards" (Meyer 2010: p. 14) they have already tacitly endorsed by joining the 191 member ICAO; in this case, ties brokered by donors take the form of aid aimed at closing decoupling gaps in civil aviation.

\section{Aid to international organizations - both INGOs and IGOs - brokering delivery of}

development programming in recipient countries: Aid frequently flows from donors to recipient countries through international non-governmental and inter-governmental actors. Donor funding plays a direct brokerage role in these instances by enabling the INGO or IGO to operate in a recipient country where it might be unable to otherwise. One example of this practice, where bilateral aid from the United Kingdom supports the work of an IGO in a recipient country, is the five-year, £75-million “DFID UNICEF Strategic Partnership in India” running from 2006-2011 which aimed to improve "government capacity for planning, monitoring, implementation, and 
community mobilisation to better realize the right (sic) of children" (DFID 2010). Again, the nexus of foreign aid, human rights, and intergovernmental agencies is combined in one aid project promoting improved Indian adherence to children's rights, something they committed to when ratifying the UN's Convention on the Rights of the Child.

Another example can be seen in Canada's support of the implementation of the Convention on the Elimination of All Forms of Discrimination Against Women (CEDAW) treaty in seven Southeast Asian states from 2003 through 2009 (CIDA 2010). Canada ratified CEDAW in 1981 and more than twenty years later funded this CAD $\$ 9.8$ million project implemented through the United Nations Development Fund for Women (UNIFEM) to support Southeast Asian governments and NGOs in "understanding of national obligations while improving the reporting and monitoring of the implementation of the Convention" (CIDA 2010). Not only does such aid aim to directly contribute to country implementation of human rights treaties, but it does so through the use of an expert executing agency that is a prominent IGO and part of the UN system. Using UNIFEM expert knowledge on the CEDAW and helping countries in Southeast Asia become better equipped to implement CEDAW sees a donor like Canada promoting world society norms of human rights and women's equality in a very direct way by brokering ties between developing countries and UNIFEM.

\section{[FIGURE 6 HERE]}

Countless other examples of this channel of aid delivery can be found when examining global aid programming data. For example, Figure 6 shows that in 2011 more than 60,000 aid projects were funded by OECD DAC donors using INGO, IGO, and other CSO implementers, for a combined total of nearly $\$ 39$ billion USD in spending. That level of spending channeled 
through INGOs, IGOs, and other civil society groups represents direct donor efforts to promote development by brokering new ties and strengthening existing ones between recipient countries and the INGO/IGO actors of world society.

\section{Network Centrality and Exposure/Emulation}

Network centrality has often been conceived of as a measure of power or influence an actor wields in a network (Hanneman and Riddle 2005). Political scientists have extended this concept to reflect the power that countries hold within international networks (Hafner-Burton et al. 2006, 2009; Montgomery Forthcoming). In the case of diffusion processes that underpin world society embeddedness, we can equate donor outdegree centrality with their influence over diffusion, while recipients' indegree centrality (ties to donors) are more accurately viewed as the extent of exposure they experience in the network (Valente 1996). Exposure in this context references to the number of network alters to which any given node is linked and whom have adopted a given policy, norm, practice, and so on. Valente (1996) demonstrates how innovation diffuses more rapidly to actors connected to a higher number of early adopters whom they emulate. For instance, a network node linked to 10 others, where 5 have already adopted a certain innovation would be seen to have an exposure value of $50 \%$. In the case of the global network, donors and their experience of implementing world society norms and models can serve as examples to recipient countries yet to adopt the same models. My findings suggest that recipients tied to a higher number of donors who have already adopted certain norms or institutions will have a higher level of exposure and be more likely to adopt them.

This can be seen in my analysis in the case of human rights treaty ratifications. If we again consider the treaty reach figures shown in Table 5, if the median recipient had donor ties to 
20 donors in 2005, and those donors had on average ratified 4 more treaties than the recipient, this would imply at least 80 instances of donor treaty ratification/implementation which the recipient might emulate. ${ }^{11}$ In this way, recipients with greater exposure to donor exemplars of treaty adoption or other institutions and policy innovations, appear more likely to adopt world society models. With more detailed network data that specifies the adoption of various world society models/norms, future research can test this exposure theory more directly than is possible here.

Through even a brief exploration of the brokerage and exposure network mechanisms it is clear that foreign aid network position can reshape certain developing states to more closely resemble donor states in their embeddedness in world society. Aid has the potential to bring greater ratification, implementation, and adherence to human rights treaties and conventions; greater memberships in international organizations; better compliance with international standards; and closer links to and participation in intergovernmental organizations who can simultaneously be active as the expert implementers of aid programs. All of these aspects of world polity embeddedness can be linked to the transnational process of bilateral development assistance. My results indicate that Western aid should be considered as a key factor when trying to explain the diffusion aspects of world society models/norms and the spread of organizational ties in the developing world.

Beyond this diffusion role - linked closely to processes of normative and expert isomorphism discussed above - I have argued that aid programming should be viewed as one of the elusive recursive mechanisms through which well-off donor states work to shape the normative and institutional content of world culture. The recursive nature of aid can be seen in 
the way in which donor states spread models which they have already adopted, institutionalized, and refined in earlier periods. Effectively, donors spread world society norms and institutional models to the developing world using aid funds to broker ties to the expertise required - via increased access to the appropriate epistemic communities and the rational others of world society - for less-developed states to reform to meet world society norms. Recipient countries that have a greater number of ties to aid donors are exposed to a wider pool of resources, expertise, and relationships upon which to draw and emulate, and underscoring the inherently relational nature of foreign aid (Peterson 2014; Swiss 2016).

\section{CONCLUSION}

Foreign aid is a transnational mechanism of political globalization. Wealthy western donor states are able to recursively assist the spread of world society institutional and policy models, and membership in the 'rational others' of world society through their contributions of aid to the developing world. This globalizing influence of aid -through network mechanisms of brokerage and exposure - has the ability to encourage recipient states to ratify international human rights treaties and conventions and to become more closely linked to the global community through greater ties to international organizations - both governmental and nongovernmental.

My findings suggest this globalizing power of aid functions not primarily through the total volumes of aid transferred, but through the community of donors active in promoting institutions within a recipient state. This suggests that it is not the magnitude of the investments embodied in a tie between donor and recipient, but the presence of the tie itself that works to connect recipients to world society. Viewing aid through a network lens shows that network 
centrality of recipients is positively associated with all aspects of world society embeddedness considered here. Donor brokerage and greater exposure to donors in the aid network matters. Yet, more detailed investigation of the shape, content, and power relationships of the global foreign aid network are required in future research, especially given the challenge posed to the bilateral aid system by the emergence of new donors like China, India, and Brazil. Likewise, a more detailed specification of brokerage processes than is possible with the current data would help shed more light on the role of aid donors brokering ties for recipient countries and whether different levels of aid spending associated with these ties impacts the brokerage process. Both of these next steps in research will help nuance my core finding here: The greater number of donors involved in providing aid to a country, the more embedded in the world polity that country is likely to be.

This research helps expand our understanding of political globalization and world society in two significant ways by speaking to the dearth of previous research on the recursive aspects of the world polity and by proposing a process through which the world polity might be able to become more equal.

First, by proposing foreign aid as a recursive mechanism through which wealthy states reshape and diffuse world society models and organizational ties to the less developed world, this article outlines a process by which states actively contribute to the evolution of the content of world culture following their own enactment of the same models. Rather than institutional isomorphism in the world polity being a unidirectional process of enactment, viewing aid as one of the recursive feedback loops from a key set of influential states who promote ties to other 
global actors begins to illustrate a pathway through which states are implicated in the refinement and spread of these same models.

Second, in response to earlier research which has shown the uneven and often unequal penetration of the world polity into developing states or the periphery of the global community, and the increasingly regional structure of the organizations that compose world society, this research argues that foreign aid is a process through which world society is actively attempting to redress some of these imbalances. This preliminary research is not able to evaluate whether aid is able to correct for the imbalance in IGO and INGO network membership of developing states relative to wealthier countries demonstrated in earlier research (Beckfield 2003, 2008; Hughes et al. 2009). It does suggest, however, that donor countries are actively engaged in providing resources for and brokering increased developing country participation in these networks, adding another wrinkle to understanding the nature of inequality in the structure of world society. With this contradiction in mind, the question of whether aid has the ability to act as a redistributive equity mechanism for world polity embeddedness is one better left for future research. Still, the presence of any international redistributive mechanism implicated in bringing the developing world more tightly into the fold of global organizational networks and international norms is a first step towards better understanding of the North-South power politics at play in the world polity. Indeed, the lack of sufficient treatment of these power issues is something for which world society research has been criticized in the past (Finnemore 1996).

By taking seriously the role country-to-country foreign aid plays in the global community and viewing it from a network perspective this article begins to explore the link between foreign aid and political globalization. Using panel data over a more than thirty-year period, my analysis 
shows that aid needs to be considered as a key transnational process through which the core of developed donor nations actively works to broker greater integration of less-developed countries into the global community via world society norms like human rights and through increased ties to intergovernmental and international non-governmental organizational networks. I suggest two network mechanisms through which bilateral aid achieve these globalizing aims and offered examples of each reflected in aid practices. Future work elaborating these mechanisms will need to investigate the isomorphic and brokering potential of aid network influences in more depth. Additional work that analyzes this relationship using sector-specific aid, INGO, and IGO data would also yield fruitful results and becomes increasingly possible as the quality of data on bilateral aid globally continues to improve. Only by detailing how aid functions in specific cases to integrate countries into the world polity will a fuller understanding of its recursive, relational, and redistributive role as a transnational process supporting globalization in world society be better understood.

\footnotetext{
${ }^{1}$ All independent variables cover the period from 1975-2005 and are lagged three years behind the dependent variables. Hence, I use explanatory variables in 1975 to predict world society embeddedness in 1978, 2005 to predict embeddedness in 2008 , and so on.

${ }^{2}$ I use random effects models in my analysis because of the need to control for the effects of the regionalization of world society in my models (See: Beckfield 2003, 2008, 2010). Hausman tests run on the full models for each dependent variable only indicate a preference for the fixed effects model specification for the INGO variable and therefore I employ the random effects model so that I can examine the influence of fixed characteristics like region. Fixed effects models for all three dependent variables show similar results to those presented here.

${ }^{3}$ Treaties included in this count are: International Convention on the Elimination of All Forms of Racial Discrimination (ICERD); International Covenant on Civil and Political Rights (ICCPR) and two optional protocols; International Covenant on Economic, Social and Cultural Rights (ICESCR); Convention on the Elimination of all forms of Discrimination Against Women (CEDAW) and its optional protocol; Convention against Torture and Other Cruel, Inhuman or Degrading Treatment or Punishment (CAT) and its optional protocol; the Convention on the Rights of the Child (CRC) and its two optional protocols; the International Convention on the Protection of the Rights of All Migrant Workers and Members of Their Families (ICRMW); and the Convention on the Rights of Persons with Disabilities (CRPD) and its optional protocol. Ratification dates for these treaties and protocols are drawn from the Nominal Commitment to Human Rights Project dataset.

${ }^{4}$ Thanks to Wes Longhofer for sharing this data.

${ }^{5}$ I tested all lags between 1 and 5 years. In each case, the effect of the focal independent variable (aid network centrality) was statistically significant at the $\mathrm{p}<0.01$ level or below and had magnitude similar to the results shown in Tables 2-4.
} 
${ }^{6}$ A negative flow of ODA, denoting a year in which a recipient paid back former ODA debt to the donor was coded as a zero, indicating no flow of ODA to the recipient in that year. There is no differentiation in the network measure between a country receiving \$1 million in aid from a donor and another receiving \$120 million.

${ }^{7}$ I repeated all models shown below using eigenvector scores as the measure of aid network centrality and the coefficients were identical in direction and very similar in terms of magnitude in each case. The correlation between the two measures in my sample of countries is $>0.67$.

${ }^{8}$ The calculation for this standardization process is to divide the value of a continuous variable by 2 times the standard deviation of the variable. This scales the normalized variables based on the number of 2-sd changes, making a one unit change in the normalized variable equivalent to moving from a relatively low to relatively high value. I ran an alternate set of models where the skewed continuous variables were log transformed and the results parallel what is presented here. I prefer Gelman's approach for ease of presentation and interpretation in contrast to log-transformed independent variables.

${ }^{9}$ Including both aid per capita and aid dependency in a single model resulted in sign-switching and distorted results because of collinearity and the strong correlation between the two measures.

${ }^{10}$ This is the case in each of Tables 2-4, suggesting that macro-level world society influences at the global and regional level also strongly shape embeddedness.

${ }^{11}$ With a tri-partite network diagram of treaties, donors, and recipients, it would be possible to calculate exposure scores for each treaty for each recipient; however, this is beyond the scope of the present study. 


\section{REFERENCES}

Achen, C.H. 2000. "Why lagged dependent variables can suppress the explanatory power of other independent variables." Paper presented at the Annual Meeting of the Political Methodology Section of the American Political Science Association. UCLA.

Babb, S.L. 2001. Managing Mexico: Economists from nationalism to neoliberalism. Princeton, NJ: Princeton Univ Press.

Barrett, Deborah, and Amy Ong Tsui. 1999. "Policy as Symbolic Statement: International Response to National Population Policies." Social Forces 78(1):213-33.

Beckfield, Jason. 2003. "Inequality in the world polity: The structure of international organization." American Sociological Review 68(3):401-24.

—. 2008. "The dual world polity: fragmentation and integration in the network of intergovernmental organizations." Social Problems 55(3):419-42.

—. 2010. "The Social Structure of the World Polity." American Journal of Sociology 115(4):1018-68.

Berkovitch, Nitza. 1999. From motherhood to citizenship : women's rights and international organizations. Baltimore, MD: Johns Hopkins University Press.

Boli, John, and George M. Thomas. 1999. Constructing world culture : international nongovernmental organizations since 1875. Stanford, CA: Stanford University Press.

Carpenter, Charli, Sirin Duygulu, Alexander H. Montgomery, and Anna Rapp. 2014. "Explaining the Advocacy Agenda: Insights from the Human Security Network." International Organization 68(02):449-70. 
Chorev, Nitsan. 2012. "Changing Global Norms through Reactive Diffusion: The Case of Intellectual Property Protection of AIDS Drugs." American Sociological Review 77(5):831-53.

CIDA. 2010. "Support to the Implementation of CEDAW in South-East Asia."

Clark, Rob. 2010. "Technical and Institutional States Loose Coupling in the Human Rights Sector of the World Polity." Sociological Quarterly 51(1):65-95.

Cole, Wade M. 2012. "Human Rights as Myth and Ceremony? Reevaluating the Effectiveness of Human Rights Treaties, 1981-2007." American Journal of Sociology 117(4):1131-71.

Cole, Wade M, and Francisco O Ramirez. 2013. "Conditional Decoupling Assessing the Impact of National Human Rights Institutions, 1981 to 2004." American Sociological Review 78(4):702-25.

Collier, P. 1999. "Aid'dependency': a critique." Journal of African Economies 8(4):528-45.

DFID. 2010. "DFID Project Search - DFID UNICEF Strategic Partnership in India."

DiMaggio, Paul, and Walter W. Powell. 1983. "The Iron Cage Revisited: Institutional Isomorphism and Collective Rationality in Organizational Fields." American Sociological Review 48(2):147-60.

Fejerskov, Adam Moe. 2015. "From Unconventional to Ordinary? The Bill and Melinda Gates Foundation and the Homogenizing Effects of International Development Cooperation." Journal of International Development 27(7):1098-112.

Finnemore, Martha. 1996. "Norms, Culture, and World Politics: Insights from Sociology's Institutionalism." International Organization 50(2):325-47.

Frank, David John. 1997. "Science, Nature, and the Globalization of the Environment, 18701990." Social Forces 76(2):409-35. 
Frank, David John, Wesley Longhofer, and Evan Schofer. 2007. "World Society, NGOs and Environmental Policy Reform in Asia." International Journal of Comparative Sociology 48(4):275-95.

Gelman, Andrew. 2008. "Scaling regression inputs by dividing by two standard deviations." Statistics in medicine 27(15):2865-73.

Gerring, J, SC Thacker, and C Moreno. 2005. "Centripetal democratic governance: A theory and global inquiry." American Political Science Review 99(04):567-81.Gould, Roger V., and Roberto M. Fernandez. 1989. "Structures of Mediation: Formal Approach to Brokerage in Transaction Networks." Sociological Methodology 19:89-126.

Granovetter, Mark S. 1973. "The strength of weak ties." American Journal of Sociology 78(6):1360-80.

Hafner-Burton, Emilie M., Miles Kahler, and Alexander H. Montgomery. 2009. "Network analysis for international relations." International Organization 63(03):559-92.

Hafner-Burton, Emilie M., and Kiyoteru Tsutsui. 2005. "Human Rights in a Globalizing World: The Paradox of Empty Promises." American Journal of Sociology 110(5):1373-411.

Hafner-Burton, Emilie M., and Alexander H. Montgomery. 2006. "Power Positions: International Organizations, Social Networks, and Conflict." Journal of Conflict Resolution 50(1):3-27.

Hughes, M.M., L. Peterson, J.A. Harrison, and P. Paxton. 2009. "Power and Relation in the World Polity: The INGO Network Country Score, 1978-1998." Social Forces 87(4):1711-42.

Jackson, JT. 2005. The globalizers: development workers in action. Baltimore, MD: Johns Hopkins University Press. 
Jang, Yong Suk. 2003. "The Global Diffusion of Ministries of Science and Technology." pp. 120-35 in Science in the modern world polity : institutionalization and globalization, edited by Gili S. Drori, John W. Meyer, Francisco O. Ramirez, and Evan Schofer. Stanford, CA: Stanford University Press.

Koo, Jeong-Woo, and Francisco O Ramirez. 2009. "National incorporation of global human rights: Worldwide expansion of national human rights institutions, 1966-2004." Social Forces 87(3):1321-53.

Meyer, John W., John Boli, George M Thomas, and Francisco O Ramirez. 1997a. "World society and the nation-state." The American Journal of Sociology 103(1):144-81.

Meyer, John W., David John Frank, Ann Hironaka, Evan Schofer, and Nancy Brandon Tuma. 1997b. "The structuring of a world environmental regime, 1870-1990." International Organization 51(4):623.

Meyer, J.W. 2010. "World society, institutional theories, and the actor." Annual Review of Sociology 36:1-20.

Montgomery, Alexander H. Forthcoming. "Centrality in Transnational Governance: How Networks of International Institutions shape Power Processes." in New Power Politics: Networks, Governance, and Global Security, edited by Deborah Avant and Oliver Westerwinter. Oxford: Oxford University Press.

Moore, S, E Eng, and M Daniel. 2003. "International NGOs and the role of network centrality in humanitarian aid operations: A case study of coordination during the 2000 Mozambique floods." Disasters 27(4):305-18. 
Moss, T., G. Petterson, and N. van der Walle. 2006. "An Aid-Institutions Paradox? A Review Essay on Aid Dependency and State Building in Sub-Sahara Africa." CGD Working Paper 74. Washington DC: Center for Global Development.

Moyo, D. 2009. Dead Aid: Why Aid Is Not Working and How There Is a Better Way for Africa. New York: Farrar Straus \& Giroux.Murdie, Amanda, and David R Davis. 2012. "Looking in the mirror: Comparing INGO networks across issue areas." The Review of International Organizations 7(2):177-202.

OECD 2013. “Creditor Reporting Service (CRS) Dataset.” Organization for Economic Cooperation and Development. Electronic Dataset.

Paxton, Pamela, Melanie M. Hughes, and Nicholas Reith. 2015. "Extending the INGO Network Country Score, 1950-2008." Sociological Science 2:287-307.

Peterson, L.P. 2011. "Foreign Aid, INGOs and Development: A Cross-National and Longitudinal Examination of the Global Development System." PhD Dissertation. Department of Sociology. Columbus, OH: The Ohio State University.

Peterson, Lindsey. 2014. "A Gift You Can't Refuse? Foreign Aid, INGOs and Development in the World Polity." Studies in Emergent Order 7:81-102.

Ramirez, Francisco O., Yasemin Soysal, and Suzanne Shanahan. 1997. "The changing logic of political citizenship: Cross-national acquisition of women's suffrage rights, 1890 to 1990." American Sociological Review 62(5):735.

Schofer, Evan, and Ann Hironaka. 2005. "The Effects of World Society on Environmental Protection Outcomes." Social Forces 84(1):25-47.

Schofer, Evan, and Wesley Longhofer. 2011. "The Structural Sources of Association." American Journal of Sociology 117(2):539-85. 
Schofer, Evan, and John W. Meyer. 2005. "The Worldwide Expansion of Higher Education in the Twentieth Century." American Sociological Review 70(6):898-920.

Täube, Volker G. 2004. "Measuring the social capital of brokerage roles." Connections 26(1):2952.

Swiss, Liam. 2009. "Decoupling Values from Action: An Event-History Analysis of the Election of Women to Parliament in the Developing World, 1945-90." International Journal of Comparative Sociology 50(1):69-95.

—. 2011. "Security Sector Reform and Development Assistance: Explaining the Diffusion of Policy Priorities among Donor Agencies." Qualitative Sociology 34(2):371-93.

—. 2012. "The Adoption of Women and Gender as Development Assistance Priorities: An Event History Analysis of World Polity Effects." International Sociology 27(1):96-119.

—. 2016. "A Sociology of Foreign Aid and the World Society." Sociology Compass 10(1):65-73.

Tvedt, Terje. 2006. "The international aid system and the non-governmental organisations: a new research agenda." Journal of International Development 18(5):677-90.

USAID. 2007. "Transparency International Sri Lanka Collaboration with ARD USAID Anti Corruption Programm."

—. 2010a. "USAID Democracy and Governance: Governance Technical Leadership Initiatives." —. 2010b. "USAID Pakistan - Fact Sheet - Democracy and Governance Program."

Ward, Michael D, Katherine Stovel, and Audrey Sacks. 2011. "Network analysis and political science." Annual Review of Political Science 14:245-64.

Wotipka, Christine M., and Francisco O. Ramirez. 2008. "World Society and Human Rights: An Event History Analysis of the Convention on the Elimination of All Forms of Discrimination Against Women." Pp. 303-43 in The Global Diffusion of Markets and 
Democracy, edited by B.A. Simmons, F. Dobbin, and G. Garrett. Cambridge: Cambridge University Press. 
FIGURE 1 - CENTRAlity SOCIOGRAMS OF Global Foreign Aid NETwORK, 1975 \& 2005

1975

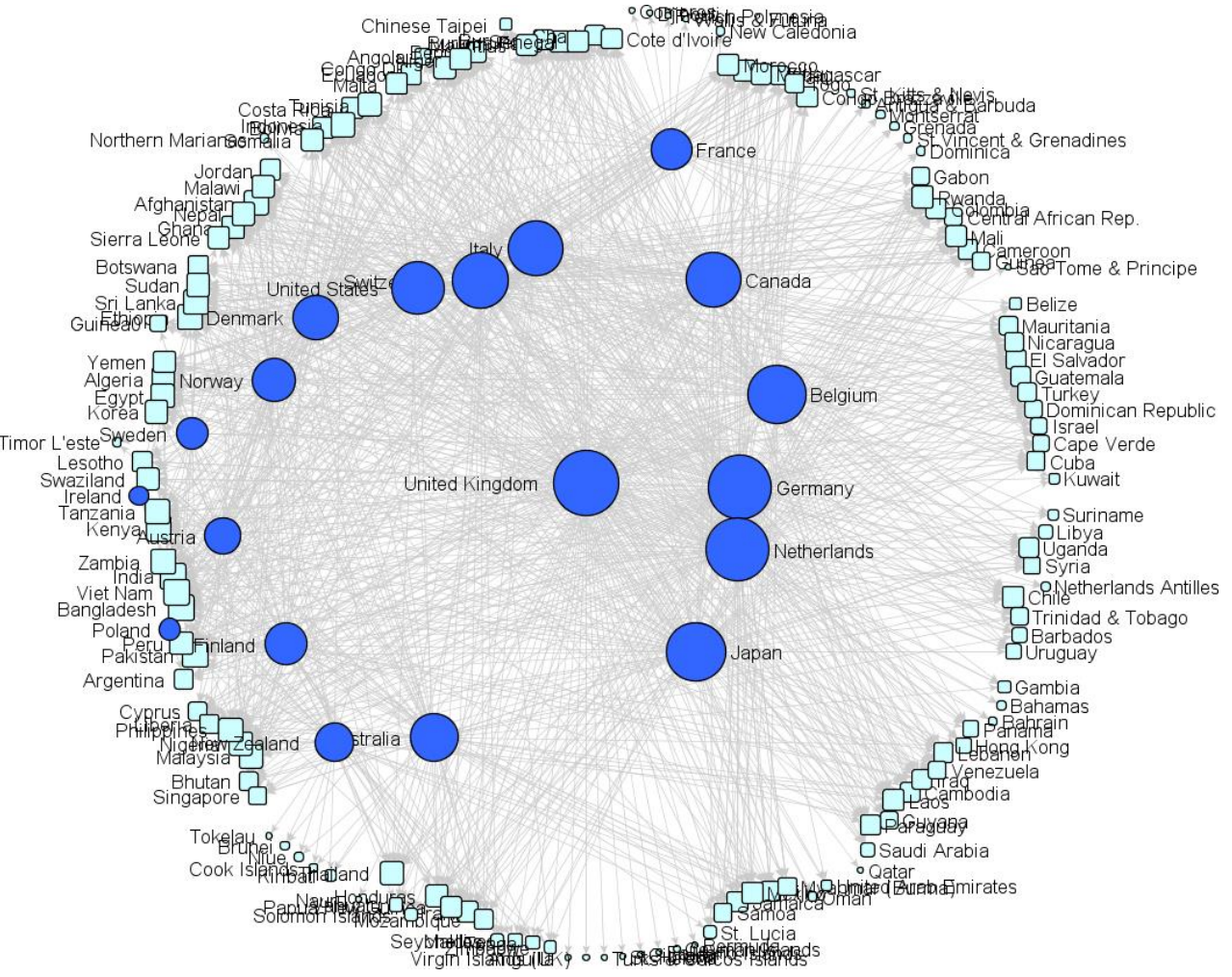

2005

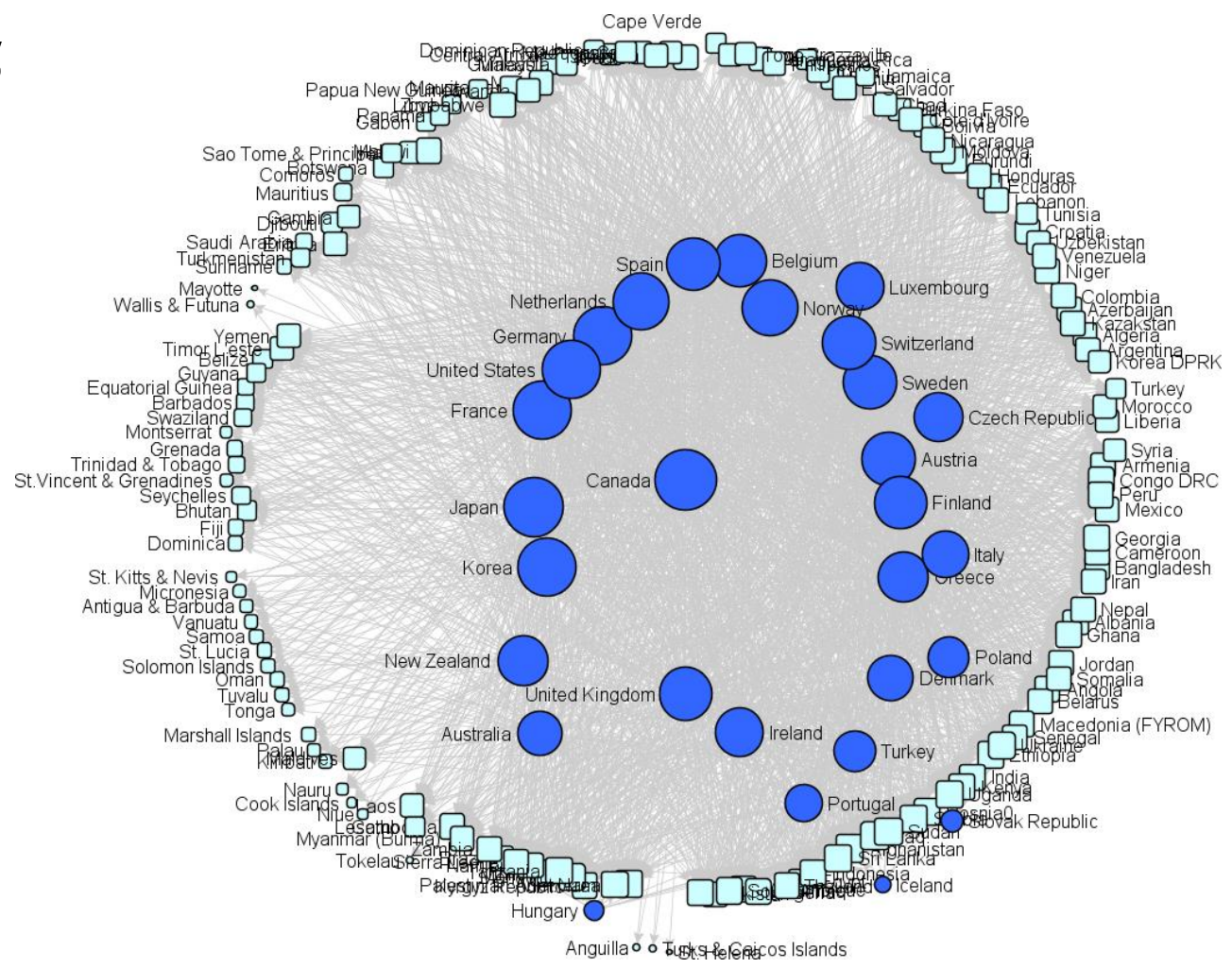


FIGURE 2 - GlobAl COUNT OF INGO MEMBERShIPS \& ForeIGN AID NETwORK TIES, 1975-2008

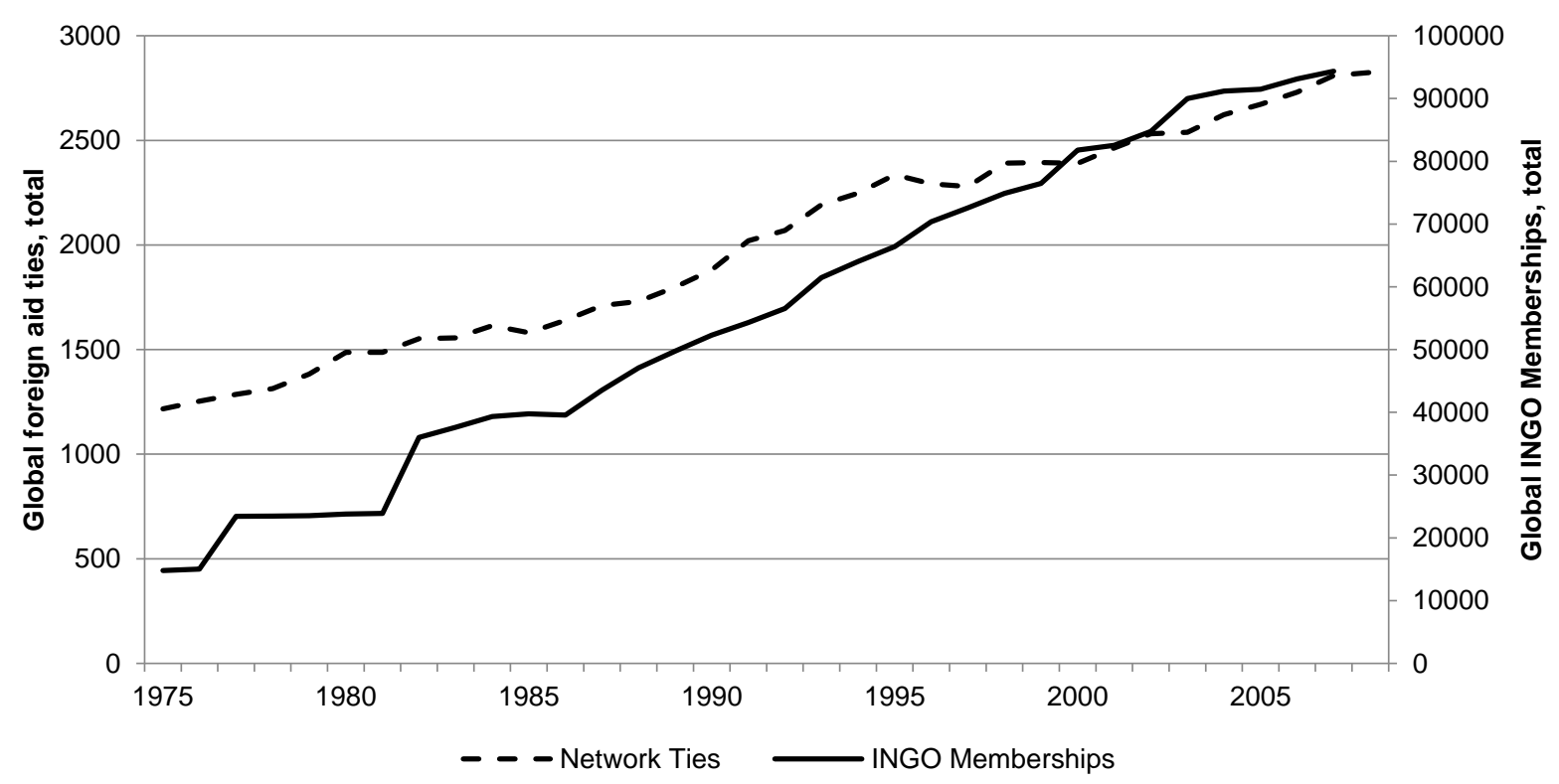


FIGURE 3 - MARGINAL EFFECT OF AID NETwORK CENTRALITY ON IGO MEMBERSHIPS AT DIFFERENT LEVELS OF GDP PER CAPITA WITH 95\% CONFIDENCE INTERVAL

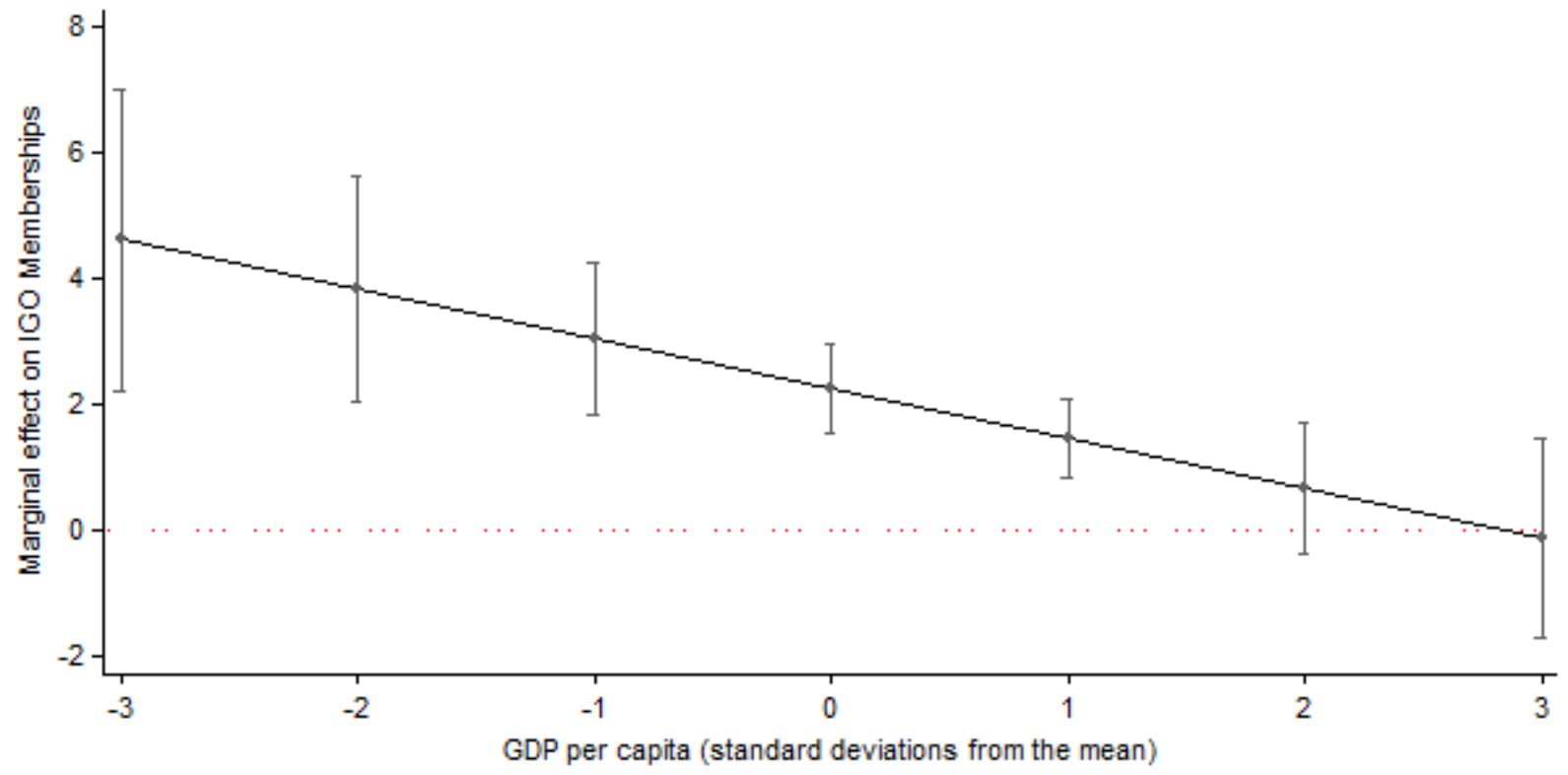


FIGURE 4 - NETWORK CENTRALITY \& DONOR BROKERAGE
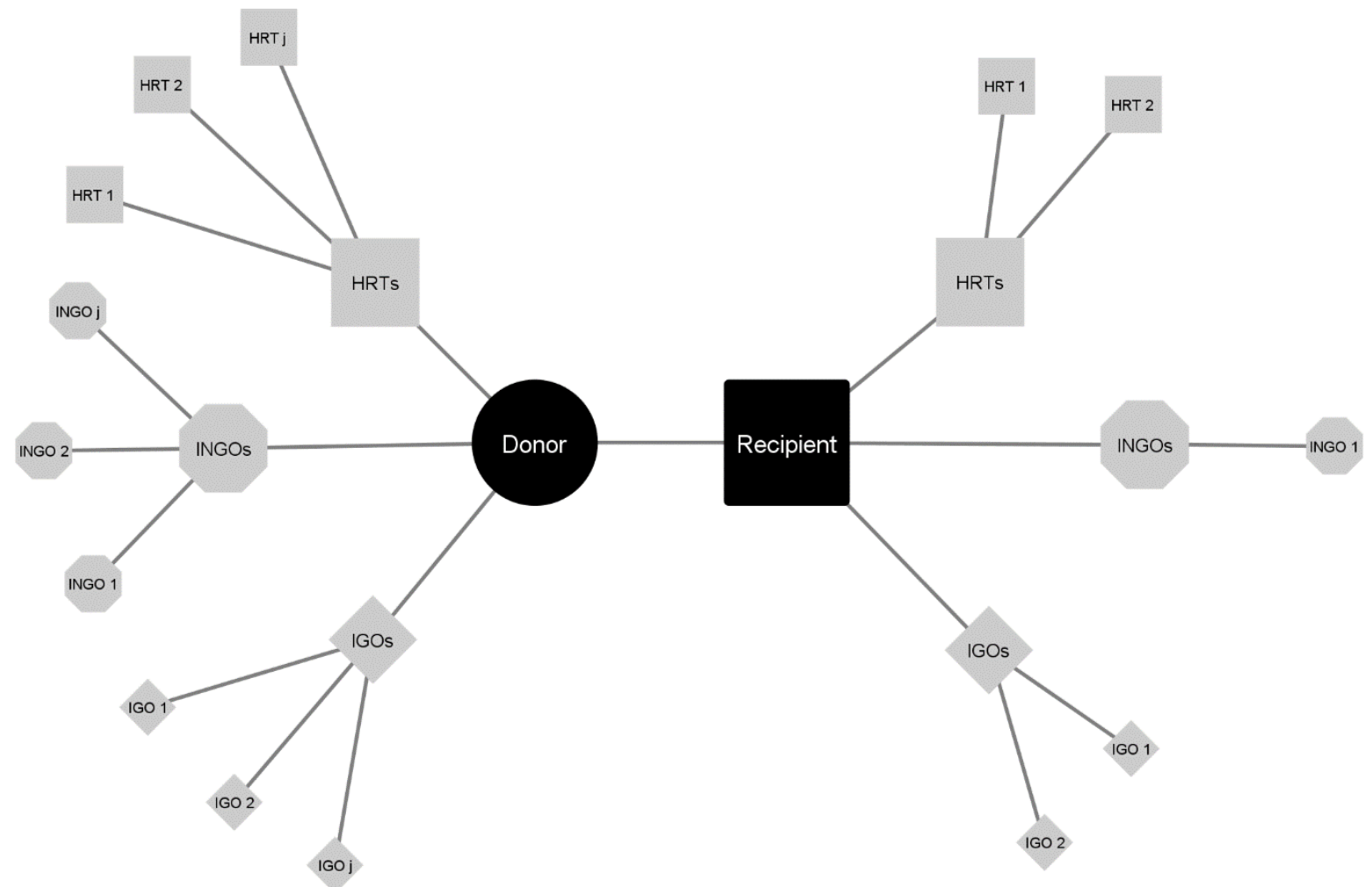
FIGURE 5 - Predicted REACH OF DONOR BROKERAGE EFFECTS, 1975-2005
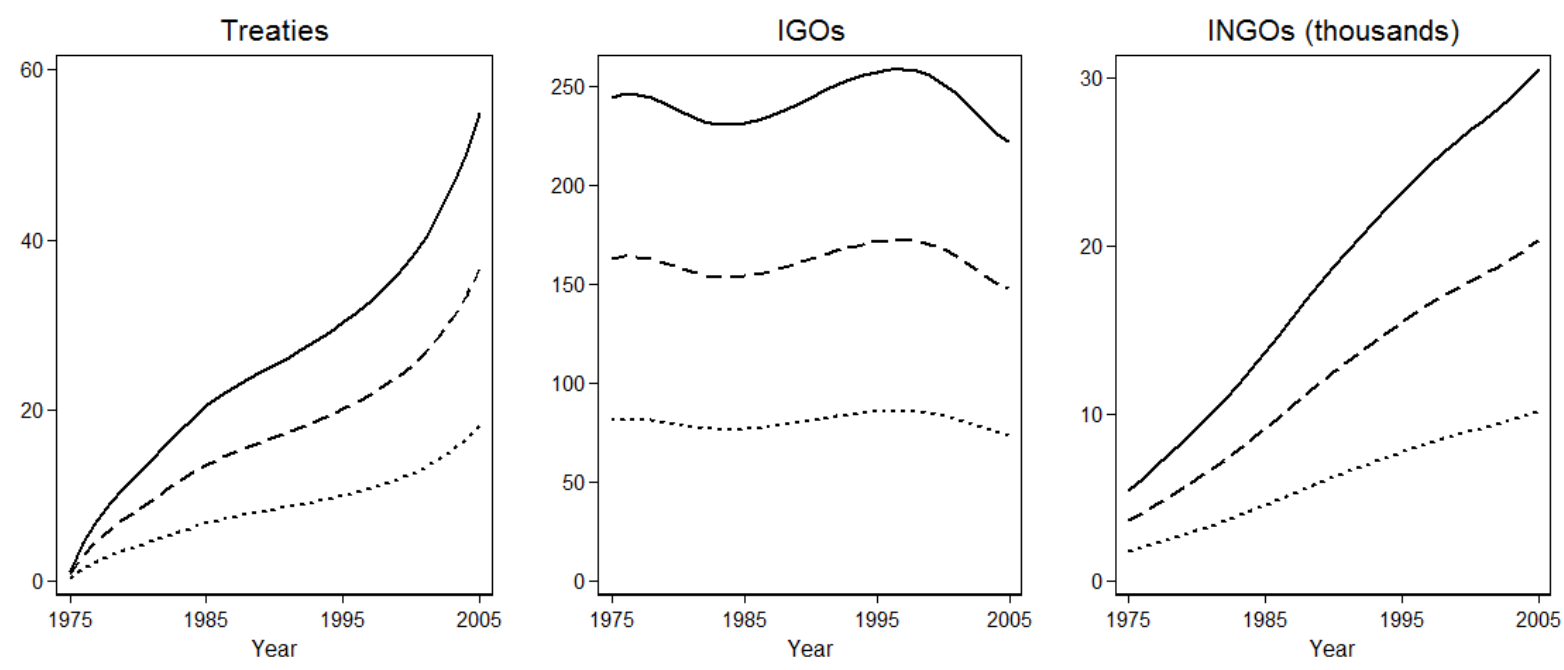

- 25\% Reach $\quad---50 \%$ Reach $\quad \cdots \cdots . .75 \%$ Reach 
FIGURE 6 - OECD DONOR PROJECTS \& DisbURSEMENTS By IMPLEMENTING CHANNEL, 2011
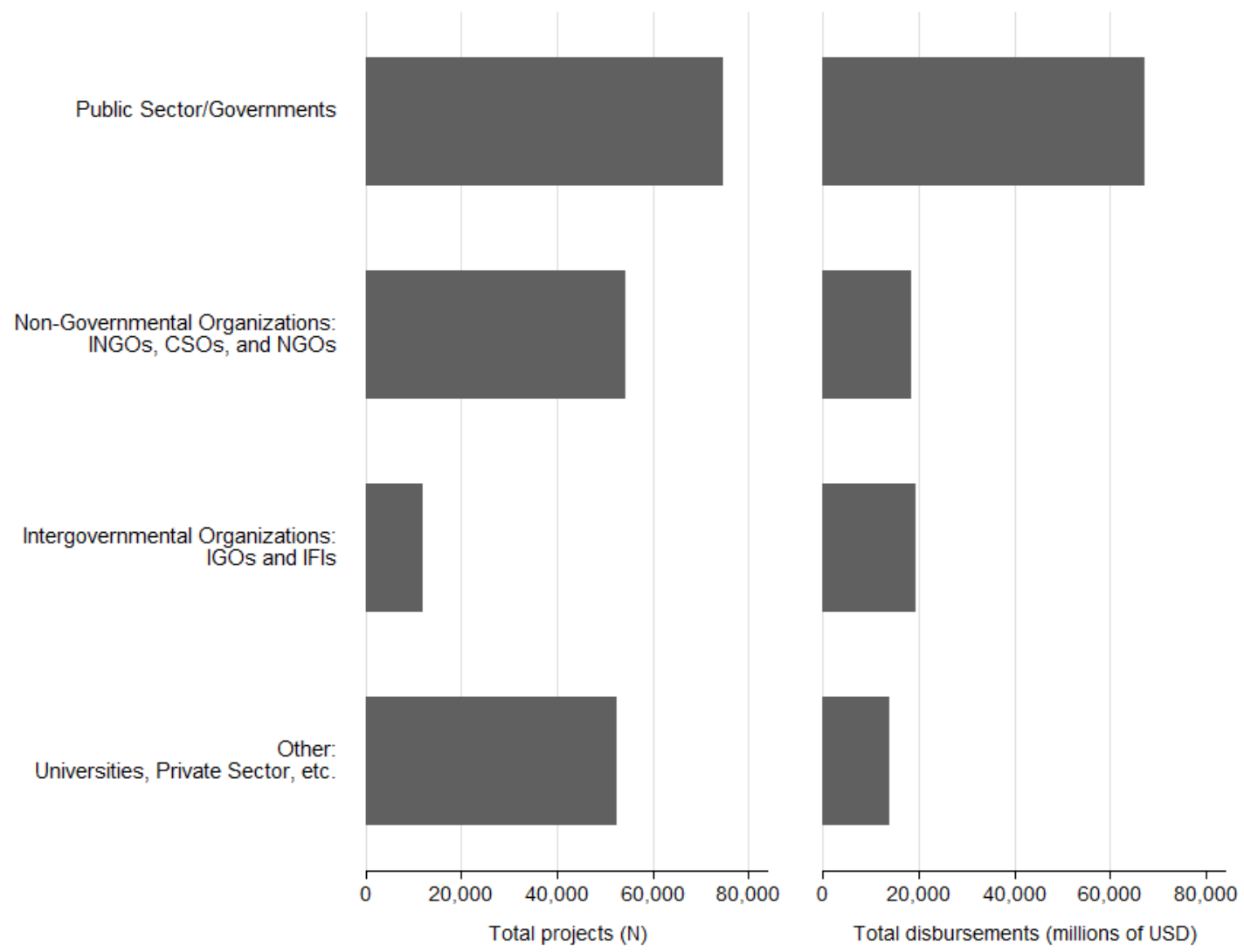

Source: OECD Creditor Reporting Service (See: OECD 2013). Channels coded into brosd categories by Author. 
TABLE 1.

Aid NeTWORK INDEGREE CENTRALITY SCORES, 1975-2005

\begin{tabular}{|c|c|c|c|c|c|c|c|}
\hline COUNTRY & 1975 & 1980 & 1985 & 1990 & 1995 & 2000 & 2005 \\
\hline Albania & - & 0 & 0 & 7 & 21 & 22 & 24 \\
\hline Algeria & 14 & 14 & 11 & 13 & 15 & 16 & 20 \\
\hline Angola & - & - & 14 & 18 & - & 22 & 23 \\
\hline Antigua \& Barbuda & - & - & 5 & 3 & 5 & 5 & - \\
\hline Argentina & 10 & 14 & 11 & 15 & 16 & 18 & 21 \\
\hline Armenia & - & - & - & - & 15 & 20 & 23 \\
\hline Azerbaijan & - & - & - & - & 14 & 17 & 22 \\
\hline Bahamas & - & 3 & 4 & 3 & 6 & 0 & - \\
\hline Bahrain & - & 6 & 3 & 5 & 4 & 3 & 0 \\
\hline Bangladesh & 18 & 18 & 18 & 20 & 21 & 23 & 22 \\
\hline Barbados & 6 & 9 & 7 & 8 & 10 & 10 & - \\
\hline Belarus & - & - & - & - & 0 & 0 & 23 \\
\hline Belize & - & - & 7 & 7 & 11 & 10 & - \\
\hline Benin & 11 & 11 & 13 & 15 & 17 & 18 & 19 \\
\hline Bhutan & - & 9 & 11 & 16 & 17 & 16 & 14 \\
\hline Bolivia & 12 & 14 & 15 & 18 & 20 & 19 & 19 \\
\hline Bosnia-Herzegovina & - & - & - & - & 16 & 25 & - \\
\hline Botswana & 11 & 14 & 16 & 16 & 18 & 16 & 16 \\
\hline Brazil & 12 & 12 & 15 & 19 & 19 & 21 & 22 \\
\hline Burkina Faso & 12 & 13 & 14 & 16 & 20 & 19 & 19 \\
\hline Burundi & 11 & 14 & 15 & 15 & 21 & 19 & 23 \\
\hline Cambodia & - & - & - & - & 20 & 22 & 23 \\
\hline Cameroon & 10 & 13 & 13 & 17 & 18 & 21 & 23 \\
\hline Cape Verde & - & 12 & 14 & 17 & 18 & 18 & - \\
\hline Central African Rep. & 8 & 10 & 12 & 12 & 17 & 16 & 17 \\
\hline Chad & 10 & 12 & 12 & 15 & 18 & 16 & 20 \\
\hline Chile & 12 & 10 & 16 & 20 & 17 & 18 & 23 \\
\hline China & 0 & 10 & 16 & 18 & 21 & 24 & 24 \\
\hline Colombia & 11 & 12 & 14 & 18 & 20 & 21 & 22 \\
\hline Comoros & - & 7 & 9 & 8 & 10 & 6 & 7 \\
\hline Congo, Dem. Rep. & 13 & 14 & 12 & 18 & 18 & 21 & 24 \\
\hline Congo, Rep. & 11 & 11 & 12 & 14 & 16 & 16 & 19 \\
\hline Costa Rica & 12 & 14 & 15 & 15 & 15 & 16 & 15 \\
\hline Cote d'Ivoire & 11 & 12 & 13 & 16 & 16 & 16 & 20 \\
\hline Croatia & - & - & - & - & 15 & 18 & 21 \\
\hline Cuba & 9 & 12 & 8 & 13 & 15 & 17 & 18 \\
\hline Cyprus & 9 & 9 & 8 & 10 & 8 & 0 & 0 \\
\hline Czech Republic & - & - & - & - & 0 & 0 & 0 \\
\hline Djibouti & - & - & - & - & 11 & 10 & 15 \\
\hline Dominica & - & 10 & 10 & 9 & 9 & 7 & - \\
\hline Dominican Republic & 8 & 12 & 11 & 15 & 17 & 14 & 14 \\
\hline Ecuador & 11 & 13 & 17 & 18 & 19 & 20 & 21 \\
\hline Egypt & 15 & 16 & 17 & 18 & 21 & 21 & 23 \\
\hline El Salvador & - & - & - & 17 & 20 & 21 & 21 \\
\hline
\end{tabular}




\begin{tabular}{|c|c|c|c|c|c|c|c|}
\hline Equatorial Guinea & - & - & 9 & 11 & 12 & 10 & 10 \\
\hline Eritrea & - & - & - & - & 19 & 22 & 21 \\
\hline Ethiopia & - & - & 18 & 21 & 21 & 24 & - \\
\hline Fiji & 10 & 10 & 9 & 10 & 13 & 8 & 9 \\
\hline Gabon & 8 & 9 & 8 & 12 & 10 & 10 & 13 \\
\hline Gambia & 4 & 15 & 15 & 18 & 17 & 18 & 19 \\
\hline Georgia & - & - & - & - & 18 & 20 & 24 \\
\hline Ghana & 14 & 15 & 15 & 20 & 19 & 19 & 25 \\
\hline Grenada & - & - & - & 6 & 8 & 7 & - \\
\hline Guatemala & 10 & 12 & 13 & 17 & 20 & 20 & 21 \\
\hline Guinea & - & - & - & 15 & 18 & 16 & 19 \\
\hline Guinea-Bissau & 7 & 15 & 13 & 15 & 17 & 16 & 15 \\
\hline Guyana & 8 & 9 & 7 & 10 & 12 & 14 & 13 \\
\hline Haiti & - & - & - & - & - & - & 19 \\
\hline Honduras & 13 & 12 & 14 & 16 & 20 & 21 & 21 \\
\hline Hungary & 0 & 0 & 0 & 0 & 0 & 0 & 0 \\
\hline India & 18 & 16 & 16 & 19 & 18 & 19 & 25 \\
\hline Indonesia & 15 & 17 & 15 & 17 & 17 & 21 & 25 \\
\hline Iran & 11 & 8 & 8 & 16 & 13 & 20 & 22 \\
\hline Jamaica & - & - & - & - & - & - & 13 \\
\hline Kenya & 16 & 16 & 18 & 20 & 21 & 20 & 25 \\
\hline Korea & 14 & 13 & 13 & 12 & 13 & 0 & 0 \\
\hline Kuwait & - & - & - & - & 4 & 0 & 0 \\
\hline Kyrgyz Republic & - & - & - & - & 17 & 20 & 23 \\
\hline Laos & - & - & 9 & 13 & 20 & 21 & 20 \\
\hline Lebanon & - & - & - & 17 & 20 & 22 & 23 \\
\hline Lesotho & 11 & 15 & 16 & 17 & 16 & 14 & 14 \\
\hline Liberia & 10 & 14 & 13 & - & - & 13 & 20 \\
\hline Libya & - & - & - & - & - & 0 & 13 \\
\hline Macedonia (FYROM) & - & - & - & - & 14 & 20 & 24 \\
\hline Madagascar & 11 & 9 & 14 & 13 & 17 & 21 & 18 \\
\hline Malawi & 13 & 14 & 15 & 18 & 20 & 21 & 23 \\
\hline Malaysia & 15 & 15 & 15 & 15 & 17 & 15 & 17 \\
\hline Mali & 11 & 12 & 13 & 15 & 18 & 22 & 21 \\
\hline Mauritania & 9 & 12 & 14 & 15 & 19 & 17 & 18 \\
\hline Mauritius & - & 12 & 13 & 13 & 15 & 14 & 11 \\
\hline Mexico & 12 & 11 & 15 & 19 & 19 & 18 & 21 \\
\hline Moldova & - & - & - & - & 0 & 19 & 23 \\
\hline Mongolia & - & - & 2 & 8 & 19 & 23 & 25 \\
\hline Morocco & 12 & 15 & 13 & 15 & 16 & 20 & 20 \\
\hline Mozambique & - & 15 & 16 & 19 & 22 & 25 & 25 \\
\hline Namibia & - & - & - & 15 & 22 & 23 & 24 \\
\hline Nepal & 14 & 15 & 17 & 20 & 21 & 22 & 23 \\
\hline Nicaragua & 9 & 15 & 16 & 19 & 21 & 21 & 22 \\
\hline Niger & 12 & 13 & 14 & 14 & 17 & 17 & 23 \\
\hline Nigeria & 15 & 15 & 15 & 19 & 19 & 23 & 23 \\
\hline Oman & 2 & 6 & 5 & 9 & 10 & 5 & 8 \\
\hline Pakistan & 17 & 16 & 15 & 17 & 18 & 21 & 25 \\
\hline Palau & - & - & - & - & 3 & 7 & - \\
\hline
\end{tabular}




\begin{tabular}{|c|c|c|c|c|c|c|c|}
\hline Panama & - & 8 & 10 & 11 & 16 & 13 & 14 \\
\hline Papua New Guinea & 11 & 12 & 11 & 16 & 17 & 16 & 13 \\
\hline Paraguay & - & - & - & - & 17 & 14 & 19 \\
\hline Peru & 14 & 17 & 17 & 19 & 21 & 23 & 24 \\
\hline Philippines & 15 & 16 & 18 & 20 & 21 & 20 & 20 \\
\hline Poland & - & - & - & 0 & 0 & 0 & 0 \\
\hline Qatar & - & - & - & - & - & 0 & 0 \\
\hline Rwanda & 12 & 11 & 14 & 18 & 21 & 23 & 22 \\
\hline Samoa & - & - & - & - & 10 & 9 & - \\
\hline Saudi Arabia & 5 & 6 & 5 & 9 & 7 & 7 & 10 \\
\hline Senegal & 12 & 13 & 14 & 17 & 19 & 22 & 23 \\
\hline Seychelles & - & 12 & 15 & 16 & 13 & 12 & - \\
\hline Sierra Leone & 12 & 17 & 15 & 16 & 19 & 20 & 23 \\
\hline Singapore & 8 & 9 & 10 & 7 & 9 & 0 & 0 \\
\hline Slovenia & - & - & - & - & 7 & 11 & 0 \\
\hline Solomon Islands & - & - & - & 7 & 10 & 6 & 7 \\
\hline South Africa & 0 & 0 & 0 & 0 & 21 & 23 & 25 \\
\hline Sri Lanka & 16 & 17 & 18 & 19 & 20 & 16 & 27 \\
\hline St. Kitts \& Nevis & - & - & 3 & 6 & 7 & 5 & - \\
\hline St.Vincent \& Grenadines & - & 2 & 6 & 6 & 8 & 6 & - \\
\hline Sudan & 14 & 16 & 17 & 20 & 22 & 22 & 28 \\
\hline Suriname & 3 & 5 & 7 & 6 & 9 & 8 & - \\
\hline Swaziland & - & - & - & 16 & 14 & 14 & 11 \\
\hline Syria & 8 & 14 & 9 & 11 & 14 & 15 & 18 \\
\hline Tajikistan & - & - & - & - & 15 & 18 & 20 \\
\hline Tanzania & - & - & - & 19 & 21 & 21 & 26 \\
\hline Thailand & 14 & 17 & 16 & 21 & 21 & 19 & 23 \\
\hline Togo & 9 & 13 & 13 & 17 & 16 & 15 & 18 \\
\hline Trinidad \& Tobago & 8 & 10 & 7 & 8 & 8 & 11 & 10 \\
\hline Tunisia & 14 & 10 & 14 & 14 & 12 & 17 & 17 \\
\hline Turkey & 9 & 14 & 9 & 15 & 13 & 16 & 14 \\
\hline Turkmenistan & - & - & - & - & 7 & 13 & 12 \\
\hline Uganda & - & - & 17 & 19 & 21 & 20 & 26 \\
\hline Ukraine & - & - & - & - & 0 & 0 & 25 \\
\hline United Arab Emirates & - & - & - & - & - & 0 & 0 \\
\hline Uruguay & 6 & 10 & 12 & 15 & 20 & 15 & 17 \\
\hline Uzbekistan & - & - & - & - & 12 & 19 & 20 \\
\hline Vanuatu & - & 6 & 8 & 7 & 6 & 7 & - \\
\hline Venezuela & 8 & 7 & 9 & 14 & 11 & 24 & 21 \\
\hline Yemen & - & - & - & 13 & 15 & 18 & 21 \\
\hline Zambia & 16 & 17 & 18 & 18 & 21 & 22 & 23 \\
\hline Zimbabwe & - & 16 & 18 & 19 & 22 & 24 & 23 \\
\hline
\end{tabular}


TABLE 2.

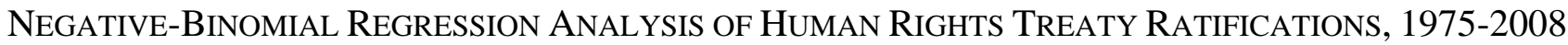

\begin{tabular}{|c|c|c|c|c|c|c|}
\hline & \multirow{2}{*}{$\begin{array}{c}\text { Controls } \\
(1)\end{array}$} & \multicolumn{3}{|c|}{ Foreign Aid } & \multicolumn{2}{|c|}{ Full Models } \\
\hline & & (2) & (3) & $(4)$ & $(5)$ & $(6)$ \\
\hline \multicolumn{7}{|l|}{ SOCIETY \& ECONOMY } \\
\hline \multicolumn{7}{|l|}{ Region (Sub-Saharan Africa) } \\
\hline North Africa/Middle East & 1.07 & $1.72 * * *$ & 1.21 & $1.30 *$ & 1.08 & 1.07 \\
\hline Asia-Pacific & $0.74 * *$ & 0.91 & 0.90 & 0.92 & $0.75 * *$ & $0.74 * *$ \\
\hline Latin America & $1.48 * * *$ & $1.45^{* * *}$ & $1.30 * *$ & $1.43 * * *$ & $1.48 * * *$ & $1.47 * * *$ \\
\hline Eastern Europe & $1.51 *$ & $3.33 * * *$ & $1.98 * * *$ & $2.27 * * *$ & $1.64 * *$ & $1.65 * *$ \\
\hline GDP per capita & 0.90 & & & & 0.95 & 0.95 \\
\hline Goods and Services Exports & 0.96 & & & & 0.97 & 0.97 \\
\hline Democracy: Polity IV Score & $1.15^{* * *}$ & & & & $1.15^{* * *}$ & $1.14 * * *$ \\
\hline \multicolumn{7}{|l|}{ WORLD SOCIETY } \\
\hline \multicolumn{7}{|l|}{ Decade (1970s) } \\
\hline $1980 \mathrm{~s}$ & $1.49 * * *$ & & & & $1.48 * * *$ & $1.49 * * *$ \\
\hline $1990 \mathrm{~s}$ & $1.87 * * *$ & & & & $1.85 * * *$ & $1.86 * * *$ \\
\hline $2000 \mathrm{~s}$ & $1.97 * * *$ & & & & $1.94 * * *$ & $1.96 * * *$ \\
\hline World Mean HRT Count & $1.54 * *$ & & & & $1.49 * *$ & $1.48 * *$ \\
\hline \multicolumn{7}{|l|}{ Regional Mean HRT Counts } \\
\hline Sub-Saharan Africa & $1.42 *$ & & & & $1.39 *$ & $1.42 *$ \\
\hline North Africa/Middle East & $1.45^{*}$ & & & & $1.40^{*}$ & $1.43^{*}$ \\
\hline Asia-Pacific & $1.64 * *$ & & & & $1.63 * *$ & $1.64 * *$ \\
\hline Latin America & 1.08 & & & & 1.06 & 1.07 \\
\hline Eastern Europe & 1.20 & & & & 1.16 & 1.16 \\
\hline \multicolumn{7}{|l|}{ FOREIGN AID } \\
\hline Aid network centrality & & $2.54 * * *$ & & & $1.10 * *$ & $1.10^{*}$ \\
\hline Aid per capita & & & $0.44 * * *$ & & $0.86^{*}$ & \\
\hline Aid dependency & & & & 1.04 & & 0.96 \\
\hline Observations & 3306 & 3306 & 3306 & 3306 & 3306 & 3306 \\
\hline Countries & 135 & 135 & 135 & 135 & 135 & 135 \\
\hline Log Likelihood & -6178.41 & -7110.68 & -7652.78 & -7690.99 & -6171.56 & -6174.54 \\
\hline AIC & 12392.83 & 14237.36 & 15321.56 & 15397.97 & 12385.12 & 12391.07 \\
\hline
\end{tabular}


TABLE 3.

\begin{tabular}{|c|c|c|c|c|c|c|}
\hline & \multirow{2}{*}{$\begin{array}{c}\text { Controls } \\
\text { (1) }\end{array}$} & \multicolumn{3}{|c|}{ Foreign Aid } & \multicolumn{2}{|c|}{ Full Models } \\
\hline & & $(2)$ & $(3)$ & $(4)$ & $(5)$ & $(6)$ \\
\hline \multicolumn{7}{|l|}{ SOCIETY \& ECONOMY } \\
\hline \multicolumn{7}{|l|}{ Region (Sub-Saharan Africa) } \\
\hline North Africa/Middle East & -29.25 & $213.57 *$ & $199.72 *$ & $199.45^{*}$ & -27.34 & -27.14 \\
\hline Asia-Pacific & 49.35 & $169.05^{*}$ & 163.65 & 163.08 & 46.54 & 46.84 \\
\hline Latin America & 164.88 & $248.67 * *$ & $239.71 * *$ & $239.46^{* *}$ & $168.25^{*}$ & $168.48 *$ \\
\hline Eastern Europe & $308.49 *$ & $698.39 * * *$ & $671.99 * * *$ & $671.80 * * *$ & $328.55 * *$ & $328.50 * *$ \\
\hline GDP per capita & $135.21 * * *$ & & & & $143.40 * * *$ & $143.46^{* * *}$ \\
\hline Goods and Services Exports & $12.30 *$ & & & & 11.17 & 11.14 \\
\hline Democracy: Polity IV Score & $19.05 * * *$ & & & & $17.81 * * *$ & $17.76^{* * *}$ \\
\hline \multicolumn{7}{|l|}{ WORLD SOCIETY } \\
\hline \multicolumn{7}{|l|}{ Decade (1970s) } \\
\hline $1980 \mathrm{~s}$ & $24.80 * * *$ & & & & $22.75 * * *$ & $22.75 * * *$ \\
\hline $1990 \mathrm{~s}$ & $45.51 * * *$ & & & & $42.49 * * *$ & $42.47 * * *$ \\
\hline $2000 \mathrm{~s}$ & $73.59 * * *$ & & & & $70.70 * * *$ & $70.69 * * *$ \\
\hline World Mean INGO Count & $99.82 * * *$ & & & & $96.52 * * *$ & $96.50 * * *$ \\
\hline \multicolumn{7}{|l|}{ Regional Mean INGO Counts } \\
\hline Sub-Saharan Africa & $-120.25 * *$ & & & & $-127.55^{* *}$ & $-127.49 * *$ \\
\hline North Africa/Middle East & 20.71 & & & & 20.03 & 20.02 \\
\hline Asia-Pacific & 11.66 & & & & 14.74 & 14.71 \\
\hline Latin America & -32.75 & & & & -34.44 & -34.43 \\
\hline Eastern Europe & $100.75 * * *$ & & & & $98.90 * * *$ & $99.03 * * *$ \\
\hline \multicolumn{7}{|l|}{ FOREIGN AID } \\
\hline Aid network centrality & & $38.60 * * *$ & & & $31.17 * * *$ & $31.11 * * *$ \\
\hline Aid per capita & & & -1.27 & & 0.49 & \\
\hline Aid dependency & & & & -0.75 & & 0.59 \\
\hline Constant & $160.22 * *$ & $237.86 * * *$ & $284.42 * * *$ & $284.65 * * *$ & $132.95 *$ & $132.78 *$ \\
\hline Observations & 3155 & 3155 & 3155 & 3155 & 3155 & 3155 \\
\hline Countries & 133 & 133 & 133 & 133 & 133 & 133 \\
\hline $\mathrm{R}^{2}$ Overall & 0.23 & 0.18 & 0.16 & 0.15 & 0.25 & 0.24 \\
\hline
\end{tabular}

Uerence categories in brackets.

$* \mathrm{p}<0.05, * * \mathrm{p}<0.01, * * * \mathrm{p}<0.001$ (two-tailed test) 
TABLE 4.

RANDOM EFFECTS REGRESSION ANALYSIS OF IGO MEMBERSHIPS, 1975-2008

\begin{tabular}{|c|c|c|c|c|c|c|}
\hline & \multirow{2}{*}{$\begin{array}{c}\text { Controls } \\
(1)\end{array}$} & \multicolumn{3}{|c|}{ Foreign Aid } & \multicolumn{2}{|c|}{ Full Models } \\
\hline & & $(2)$ & (3) & $(4)$ & $(5)$ & $(6)$ \\
\hline \multicolumn{7}{|l|}{ SOCIETY \& ECONOMY } \\
\hline \multicolumn{7}{|l|}{ Region (Sub-Saharan Africa) } \\
\hline North Africa/Middle East & $7.56^{*}$ & $9.01 * *$ & $8.19 * *$ & $8.28 * *$ & $7.21 *$ & $7.27 *$ \\
\hline Asia-Pacific & $-6.63 *$ & $-7.33 * *$ & $-7.53 * *$ & $-7.57 * *$ & $-6.70 *$ & $-6.77 *$ \\
\hline Latin America & -1.88 & 2.53 & 2.09 & 2.17 & -1.94 & -1.93 \\
\hline Eastern Europe & -7.22 & 0.02 & -1.44 & -1.35 & -6.22 & -6.26 \\
\hline GDP per capita & $2.51 *$ & & & & $3.02 * *$ & $3.04 * *$ \\
\hline Goods and Services Exports & 0.10 & & & & 0.03 & 0.02 \\
\hline Democracy: Polity IV Score & 0.46 & & & & 0.32 & 0.33 \\
\hline \multicolumn{7}{|l|}{ WORLD SOCIETY } \\
\hline \multicolumn{7}{|l|}{ Decade (1970s) } \\
\hline $1980 \mathrm{~s}$ & $3.07 * * *$ & & & & $2.90 * * *$ & $2.90 * * *$ \\
\hline $1990 \mathrm{~s}$ & $3.06 * * *$ & & & & $2.76 * * *$ & $2.76 * * *$ \\
\hline $2000 \mathrm{~s}$ & $3.84 * * *$ & & & & $3.48 * * *$ & $3.47 * * *$ \\
\hline World Mean IGO Count & -0.36 & & & & -0.38 & -0.38 \\
\hline \multicolumn{7}{|l|}{ Regional Mean IGO Counts } \\
\hline Sub-Saharan Africa & $1.43 * *$ & & & & $1.30 * *$ & $1.29 * *$ \\
\hline North Africa/Middle East & 0.73 & & & & 0.79 & 0.78 \\
\hline Asia-Pacific & 1.10 & & & & 1.08 & 1.08 \\
\hline Latin America & $2.18 * * *$ & & & & $2.17 * * *$ & $2.17 * * *$ \\
\hline Eastern Europe & $3.11 * * *$ & & & & $3.00 * * *$ & $3.03 * * *$ \\
\hline \multicolumn{7}{|l|}{ FOREIGN AID } \\
\hline Aid network centrality & & $2.19 * * *$ & & & $1.75 * * *$ & $1.73 * * *$ \\
\hline Aid per capita & & & -0.12 & & -0.10 & \\
\hline Aid dependency & & & & 0.19 & & 0.17 \\
\hline Constant & $34.85^{* * *}$ & $37.46^{* * *}$ & $40.10 * * *$ & $39.98 * * *$ & $33.45 * * *$ & $33.40 * * *$ \\
\hline Observations & 3141 & 3141 & 3141 & 3141 & 3141 & 3141 \\
\hline Countries & 133 & 133 & 133 & 133 & 133 & 133 \\
\hline $\mathrm{R}^{2}$ Overall & 0.10 & 0.15 & 0.11 & 0.11 & 0.13 & 0.13 \\
\hline
\end{tabular}

Uerence categories in brackets.

$* \mathrm{p}<0.05, * * \mathrm{p}<0.01, * * * \mathrm{p}<0.001$ (two-tailed test) 
TABLE 5

DONOR BROKERAGE \& REACH ESTIMATES, 1975-2005*

\begin{tabular}{|c|c|c|c|c|c|c|c|c|}
\hline \multirow[b]{3}{*}{ Indegree Centralit } & \multicolumn{7}{|c|}{ YEAR } & \multirow[b]{2}{*}{ TOTAL } \\
\hline & 1975 & 1980 & 1985 & 1990 & 1995 & 2000 & 2005 & \\
\hline & & & & & & & & \\
\hline Median donor ties & 11 & 12 & 13 & 15 & 17 & 17 & 20 & 15 \\
\hline \multicolumn{9}{|l|}{ HRTs } \\
\hline Median difference & 0 & 2 & 2 & 3 & 2 & 2 & 4 & 2.1 \\
\hline Reach $(100 \%)$ & 0 & 24 & 26 & 45 & 34 & 34 & 80 & 34.7 \\
\hline Reach $(75 \%)$ & 0 & 18 & 19.5 & 33.8 & 25.5 & 25.5 & 60 & 26 \\
\hline Reach $(50 \%)$ & 0 & 12 & 13 & 22.5 & 17 & 17 & 40 & 17.4 \\
\hline Reach $(25 \%)$ & 0 & 6 & 6.5 & 11.3 & 8.5 & 8.5 & 20 & 8.7 \\
\hline \multicolumn{9}{|l|}{ INGOs (thousands } \\
\hline Median difference & 0.7 & 0.9 & 1.3 & 1.7 & 1.9 & 2 & 2 & 1.5 \\
\hline Reach $(100 \%)$ & 7.7 & 10.8 & 17 & 24.9 & 33.1 & 34.5 & 40.6 & 24.1 \\
\hline Reach $(75 \%)$ & 5.8 & 8.1 & 12.7 & 18.7 & 24.8 & 25.9 & 30.4 & 18.1 \\
\hline Reach $(50 \%)$ & 3.9 & 5.4 & 8.5 & 12.4 & 16.5 & 17.3 & 20.3 & 12 \\
\hline Reach (25\%) & 1.9 & 2.7 & 4.2 & 6.2 & 8.3 & 8.6 & 10.1 & 6 \\
\hline \multicolumn{9}{|l|}{ IGOs } \\
\hline Median difference & 29.5 & 29.5 & 24 & 18 & 24 & 18 & 16.5 & 22.8 \\
\hline Reach $(100 \%)$ & 324.5 & 354 & 312 & 270 & 408 & 306 & 330 & 329.2 \\
\hline Reach $(75 \%)$ & 243.4 & 265.5 & 234 & 202.5 & 306 & 229.5 & 247.5 & 246.9 \\
\hline Reach $(50 \%)$ & 162.3 & 177 & 156 & 135 & 204 & 153 & 165 & 164.6 \\
\hline Reach $(25 \%)$ & 81.1 & 88.5 & 78 & 67.5 & 102 & 76.5 & 82.5 & 82.3 \\
\hline
\end{tabular}

*Reach $=$ median indegree centrality $\times$ median donor/recipient difference $\times$ reach multiplier 